\title{
NGF Regulates the PC12 Cell Cycle Machinery Through Specific Inhibition of the Cdk Kinases and Induction of Cyclin D1
}

\author{
Guo-zai Yan and Edward B. Ziff \\ Howard Hughes Medical Institute, Department of Biochemistry, and Kaplan Cancer Center, New York University \\ Medical Center, New York, New York 10016
}

\begin{abstract}
We have examined the effects of NGF on components of the PC12 cell cycle machinery. We show that NGF represses over 6-8 d the levels of specific cdk kinase proteins and the G2-M phase specific cyclin B1 and the $S$ phase marker PCNA as well as the level of phosphorylation of the retinoblastoma ( $R \mathrm{~B})$ protein. All of these changes may provide a basis for a NGF block to cell cycling. Unexpectedly, the G1 phase-specific cyclin D1 was dramatically increased by inducers of differentiation (NGF and FGF), but not by inducers of proliferation (EGF and insulin). Although the levels of cyclin D1/cdk2 and cyclin D1/cdk4 complexes increased following NGF treatment, as did cyclin D1/Rb complexes, the associated kinase activities declined, indicating that NGF also induces an inhibitor of cdk kinase activity. In agreement, NGF induced the cdk inhibitory protein, p21, which was found in cyclin D1/cdk kinase complexes after NGF treatment. We show that vector over expression of cyclin D1 in PC12 is sufficient on its own to arrest the cells in G1 phase and inhibit expression of PCNA. These results indicate that NGF induction of cyclin D1 and inactivation of cdk kinases, the latter possibly by increase of p21, play a central role in the NGF block of PC12 cell cycling.
\end{abstract}

[Key words: NGF, PC12 cells, differentiation, G1 arrest, cdks, cyclin D1]

Neuronal development entails a complex series of events involving growth arrest, sequential activation of specific genes, and neuronal differentiation. Terminally differentiated neurons are arrested in the postmitotic state and several key regulators of the cell cycle are downregulated (Hayes et al., 1991; Okano et al., 1993; Freeman et al., 1994). For example, cdc2 and cyclin A were downregulated in the developing CNS, concomitant with the cessation of cell proliferation (Hayes et al., 1991). This finding suggests that the downregulation of expression of certain cell cycle functions may be responsible for exit of neuronal precursors from the cell cycle during neuronal differentiation.

NGF is crucial for the growth, differentiation and survival of sympathetic and sensory neurons of peripheral neurons system

\footnotetext{
Received Feb. 13, 1995; revised May 8, 1995; accepted May 17, 1995

We thank Dr. David Beach for antibodies to cyclin D1 and cdk5, Dr. Charles Sherr for cdk4 antibody, Dr. Matthew Meyerson for cdk6 antibody, Dr. James Roberts for cyclin E antibody, and Dr. Ed Harlow for Rb (XZ133) antibody. This research was supported by a grant from the American Cancer Society. VAX computing was supported by National Science Foundation grand DIR8908095. G.-Z.Y. is an Associate and E.B.Z. an Investigator of the Howard Hughes Medical Institute.

Correspondence should be addressed to Dr. Edward B. Ziff, Department of Biochemistry, NYU Medical Center, 550 First Avenue, New York, NY 10016. Copyright $(\mathcal{O} 1995$ Society for Neuroscience 0270-6474/95/156200-13\$05.00/0
}

(PNS) and of the cholinergic neurons of the CNS (Levi-Montalcini and Angeletti, 1968; Levi-Montalcini, 1976; Johnson et al., 1980). NGF also promotes neuronal differentiation of the rat pheochromocytoma cell line, PC12, which resemble adrenal chromaffin cells of neural crest origin (Greene and Tishler, 1976). In culture, treatment of $\mathrm{PC} 12$ cells with NGF leads to slowing or cessation of the cell division and differentiation into sympathetic neuron-like cells with neurite outgrowth (Greene and Tishler, 1976; Ignatius et al., 1985; Rudkin et al., 1989). The mechanism by which NGF arrests PC12 cell cycling and promotes differentiation is not fully understood. In addition to a decrease in the proliferation rates and DNA synthesis (Greene and Tischler, 1976; Gunning et al., 1981; Ignatius et al., 1985; Buchkovich and Ziff, 1994), NGF is reported to arrest an asynchronous population of $\mathrm{PC} 12$ cells in the G0/G1 phase of the cell cycle (Rudkin et al., 1989). NGF-induced neurite outgrowth and the appearance of $\mathrm{Na}^{+}$channels occur more rapidly in $\mathrm{PC} 12$ cells arrested in G0 phase than in asynchronously growing cells (Rudkin et al., 1989). This suggests that the development of these neuronal characteristics is linked to cell arrest in G0 phase.

The proliferation of eukaryotic cells is controlled at specific points in the cell cycle, particularly at the G1 to S and the G2 to $\mathrm{M}$ transitions. Different cdks have different functional specificities based on the time of their activity during the cell cycle and their specific cyclin partner (Pines and Hunter, 1991; Pines, 1993; Sherr, 1993). Cdc2 kinase forms complexes with cyclin $\mathrm{A}$ and $\mathrm{B}$ which act at the G2/M transition and are required for entry into mitosis in multicellular eukaryotes (Riabowal et al., 1989; Pines and Hunter, 1989; Solomon et al., 1990; Pagano et al., 1992). Cdk2 is essential for the G1/S transition when associated with A, E, and D-type cyclins (Elledge et al., 1992; Pagano et al., 1992; Tsai et al., 1991, 1993a; Xiong et al., 1992; van den Heuvel and Harlow, 1993). Cdk4, cdk5, and cdk6 can form complexes with D-type cyclins in the G1 phase of the cell cycle (Matsushime et al., 1992; Xiong et al., 1992; Bates et al., 1994; Meyerson and Harlow, 1994). In macrophages and fibroblasts, cdk4 appears to be the most prominent partner of D-type cyclins (Matsushime et al., 1992; Xiong et al., 1992), while in peripheral blood T cells, cyclin D1 complexes with cdk6 predominate (Meyerson and Harlow, 1994).

Recent studies have identified additional regulatory subunits for cdks, the cdk inhibitory proteins, including p21, p27, and p16 (reviewed by Peter and Herskowitz, 1994) which bind the cdk-cyclin complex and inhibit its activity. p21 levels are elevated upon DNA damage in G1 in a p53-dependent manner (ElDeiry et al., 1993; 1994; Dulic et al., 1994). Levels of p21 protein are increased in senescent cells and p21 overexpression 
blocks the growth of tumor cells (El-Deiry et al., 1993; Harper et al., 1993; Noda et al., 1994). Recent evidence shows that p21 may directly block DNA replication by inhibiting PCNA, suggesting that inhibition of PCNA by p21 may be important for coordinating cell-cycle progression, DNA replication and repair of damage DNA (Flores-Rozas et al., 1994; Waga et al., 1994).

The D-type cyclins are thought to provide a link between the cell cycle, signal transduction and proliferation. The D-type cyclins can been induced by growth factors. Consistent with a role in proliferation, cyclin D1 was identified as a potential oncogene which is overexpressed in a variety of different tumors. An increase of cyclin D1 mRNA upon induction of leukemia cell line differentiation was observed (Akiyama et al., 1993). However, overexpression of cyclin D2 and D3 (but not D1) inhibited 32D myeloid cell differentiation induced by granulocyte colony-stimulating factor (G-CSF) (Kato and Sherr, 1993). MN20, a D2 cyclin, serves regionally specific functions in neuronal differentiation (Ross and Risken, 1994). It has been reported that cyclin D1 is selectively induced in postmitotic neurons undergoing programmed cell death (Freeman et al., 1994). Recent evidence indicates that downregulation of cyclin D1 is necessary for PCNA relocation to the nucleus and for repair DNA synthesis as well as for the start of DNA replication (Pagano et al., 1994). These findings suggest that cyclin D1 may have multiple functions in controlling cell proliferation and differentiation in varinus cell types.

We have used PC12 cells as a model system to study the regulation of the cell cycle during NGF-induced neuronal differentiation, in particular the roles of the cdc2-related kinases and cyclins. We show that NGF represses the levels of specific cdk kinase proteins and the G2-M phase specific cyclin B1 and the $\mathrm{S}$ phase marker PCNA as well as the level of phosphorylation of the retinoblastoma $(\mathrm{Rb})$ protein. Unexpectedly, the $\mathrm{G} 1$ phase-specific cyclin D1 was dramatically increased by inducers of differentiation (NGF and FGF), but not by inducers of proliferation (EGF and insulin). Although the levels of cyclin D1/cdk2 and cyclin D1/cdk4 complexes increased following NGF treatment, as did cyclin D1/Rb complexes, the associated kinase activities declined, indicating that NGF also induces an inhibitor of cdk kinase activity. In agreement, NGF induced the cdk inhibitory protein, $\mathrm{p} 21$, which was found in cyclin D1/cdk kinase complexes after NGF treatment. NGF also led to accumulation of unphosphorylated $\mathrm{Rb}$ and an increase in the levels of the D1/Rb complexes. Finally, we show that overexpression of cyclin D1 arrests the cells in $\mathrm{G} 1$ phase and inhibits expression of PCNA. These results indicate that NGF induction of cyclin D1 and inhibition of PCNA expression as well as the cyclin D1-cdk kinases by $\mathrm{P} 21$ play a central role in NGF arrest of PC12 cell cycling.

\section{Materials and Methods}

Cell culture and labeling. $\mathrm{PC} 12$ cclls wcre maintaincd in Dulbceco's modified Eagle medium (DMEM, GIBCO) containing 10\% defined and supplemented calf serum, 5\% equine serum (heat-inactivated; Hyclone Laboratories, Sterile Systems, Inc.), $100 \mu \mathrm{g} / \mathrm{ml}$ penicillin and streptomycin, in a humidified $37^{\circ} \mathrm{C}$ incubator with $10 \% \mathrm{CO}_{2}$ atmosphere. $\mathrm{PC} 12$ cells which had been stably transfected with the adenovirus Ela gene, "gE1a-PC12 cells" (Boulukos and Ziff, 1993), were cultured under the same conditions as PC12 cells. 6-24 cells overexpressing p140trk (Hempstead et al., 1992) were cultured in DMEM medium supplemented with $5 \%$ calf serum, $10 \%$ horse serum (heat inactivated, GIBCO-BRL, Inc.). Cells were plated on collagen coated dishes at the density of $-2 \times 10^{6}$ cells $/ 10 \mathrm{~cm}$ dish or $\sim 5 \times 10^{6}$ cells $/ 25 \mathrm{~cm}$ dish prior to all experiments.

Treatment with NGF at $50 \mathrm{ng} / \mathrm{ml}$; (2.5S NGF; Harlan Bioproducts for
Science), or EGF at $10 \mathrm{ng} / \mathrm{ml}$ (Boehringer Mannheim Biochemicals, Inc.), or bFGF at $20 \mathrm{ng} / \mathrm{ml}$ (Upstate Biotechnology, Inc.) in the presence of 50 $\mathrm{ng} / \mathrm{ml}$ heaparin (Sigma Chemical, Co.), or insulin at $10 \mu \mathrm{g} / \mathrm{ml}$ (GIBCO$\mathrm{BRL}$, Inc.) was performed $24 \mathrm{hr}$ after plating. $\mathrm{MgCl}_{2}(10 \mathrm{~mm})$ was routinely included in the culture medium when NGF was used (Kalman et al., 1993). Fresh medium containing NGF, or EGF, or bFGF, or insulin was used to replace $50 \%$ of the old medium every another day.

Metabolic labeling of cells was as described by Buchkovich and Ziff (1994). Briefly, $2 \mathrm{ml}$ of labeling media was added to each $10 \mathrm{~cm}$ dish containing $1.0 \mathrm{mCi}$ of ${ }^{32} \mathrm{P}$-orthophosphate $(\mathrm{NEN})$, and cells were incubated for $4 \mathrm{hr}$.

Antibodies. The rabbit polyclonal cdc 2 antibody was raised against a synthetic peptide corresponding to the C-terminal sequences of cdc2 (CLDNQIKKM). Affinty-purified peripherin antibody was previously described (Gorham et al., 1990). Polyclonal cdk2, cyclin D, and A antibodies were obtained from Upstate Biotechnology, Inc. All three of these antibodies were raised against synthetic peptides corresponding to the respective antigenic C-terminal sequences. Polyclonal cdk4, cdk6 (PLSTIRE), and Rb antibodies raised against synthetic peptides were obtained from Santa Cruz Biotechnology, Inc. Polyclonal p21 antibody was obtained from Pharmingen Inc. Monoclonal cyclin B I and PCNA antibodies were obtained from Upstate Biotechnology, Inc., and Oncogene Science, Inc., respectively. The cdk5 and cyclin D1 antisera were generously provided by Dr. David Beach. The cdk6, cdk4, cyclin $\mathrm{E}$ antisera and the $\mathrm{Rb}$ monoclonal antibody XZ133 were kindly provided by Drs. Matthew Meyerson, Charles Sherr, James Roberts, and Fd Harlow, respectively.

Immunoprecipitation and Western blot analysis. Cells were harvested by scraping from dishes and lysis in ice-cold lysis buffer $[50 \mathrm{~mm}$ Hepes (pH 7.0), $250 \mathrm{~mm} \mathrm{NaCl}, 0.1 \% \mathrm{NP}-40,1 \mathrm{~mm}$ phenylmethysulfonyl fluoride (PMSF), $1 \mu \mathrm{g} / \mathrm{ml}$ leupeptin, $1 \mu \mathrm{g} / \mathrm{ml}$ aprotinin, $1 \mu \mathrm{g} / \mathrm{ml}$ pepstatin, $10 \mathrm{~mm}$ sodium fluoride, $5 \mathrm{~mm}$ dithithreitol] by passing through a 21 gauge needle several times, and incubation for $30 \mathrm{~min}$ on ice. Insoluble cellular components were cleared by centrifugation. Protein concentration was determined using Bio-Rad Protein Concentration Reagent.

Equal amounts of lysates ( $20 \mu \mathrm{g}$ of protein per lane) were heated to $100^{\circ} \mathrm{C}$ for $3 \mathrm{~min}$ in Laemmli sample buffer, and run on $10 \%$ SDS-PAGE gels and blotted onto nitrocellulose. Western blots were performed using the Amersham ECL kit following the manufacturer's instructions ( $A$ mersham, Chicago, IL). The primary antibodies were used at 1:2000 dilution for cdc2 and cdk5, 1:3000 dilution for cyclin $\mathrm{E}$, and $1 \mu \mathrm{g} / \mathrm{ml}$ dilution for cdk2, cyclin D1, cyclin A, cyclin B1, PCNA, cdk4, and cdk6 in TBST buffer (10 mM Tris-HCl, PH 8.0, $150 \mathrm{~mm} \mathrm{NaCl}, 0.05 \%$ Tween-20). The secondary antibody was donkey anti-rabbit Ig F(ab') conjugated to horseradish peroxidase (Amersham, Chicago, IL), used at 1:5000 dilution in the same buffer.

For immunoprecipitation followed by Western blot analysis and in vitro kinase assays, immune complexes of the cdc2-related kinases and cyclin D1 were precipitated by incubating cell lysates ( $200 \mathrm{ug}$ protein) with antibodies to cdc2 $(5 \mu \mathrm{l} / \mathrm{ml})$, or cdk2 $(2 \mu \mathrm{g} / \mathrm{ml})$, or cdk4 $(1 \mu \mathrm{g} /$ $\mathrm{ml})$, or cdk5 $(5 \mu \mathrm{l} / \mathrm{ml})$, cdk6 $(5 \mu \mathrm{l} / \mathrm{ml})$, or cyclin D1 $(2 \mu \mathrm{g} / \mathrm{ml})$, or normal rabbit serum (NRS) $(5 \mu \mathrm{l} / \mathrm{ml})$ on ice for $1 \mathrm{hr}$. The complexes were then collected by rocking in $50 \mu \mathrm{l}$ of $10 \%$ protein A-Sepharose beads (Pham macia Biolechmology Inc.) for $1 \mathrm{hr}$ at $4^{\circ} \mathrm{C}$, and washed four times with lysis buffer. The immunoprecipited beads were either analyzed by Western blotting or used for in vitro kinase assays.

For radioimmunoprecipitation, $100 \mu \mathrm{l}$ of $10 \%$ protein A-Sepharose beads and $3 \mu \mathrm{l}$ normal rabbit serum were added to $0.9 \mathrm{ml}$ of lysates ( $300 \mu \mathrm{g}$ protein), and rocked for $1 \mathrm{hr}$ at $4^{\circ} \mathrm{C}$. After removal of the beads by centrifugation, $100 \mu \mathrm{l}$ of tissue culture supernatant of hybridoma cells expressing a mouse monoclonal antibody to the $\mathrm{Rb}$ protein, (XZ133, Hu et al., 1991) was added, and incubated for $1 \mathrm{hr}$ on ice. Following addition of a mouse monoclonal antibody, $3 \mu \mathrm{g}$ of rabbit anti-mouse Ig G1 (Pharmingen) was added to the solution for $30 \mathrm{~min}$. The immune complexes were then collected by rocking in $100 \mu \mathrm{l}$ of $10 \%$ protein $\mathrm{A}-$ Sepharose beads for $1 \mathrm{hr}$ at $4^{\circ} \mathrm{C}$. The immunoprecitates were washed, denatured, and separated on $7.5 \%$ SDS-PAGE gel.

In vitro kinase assays. For assay of kinase activities, cells were lysed in lysis buffer ( $50 \mathrm{mM}$ HEPES, pH 7.5, $150 \mathrm{~mm} \mathrm{NaCl}, 1 \mathrm{~mm}$ EDTA, $2.5 \mathrm{~mm}$ EGTA, $1 \mathrm{~mm}$ DTT, 0.1\% Tween-20, $10 \%$ glycerol, $0.1 \mathrm{~mm}$ PMSF, $10 \mu \mathrm{g} / \mathrm{ml}$ leupeptin, $10 \mathrm{~mm} \beta$-glycerophosphate, $0.1 \mathrm{~mm}$ sodium orthovanadate, $1 \mathrm{mM} \mathrm{NaF}, 1 \mu \mathrm{g} / \mathrm{ml}$ aprotinin), following by sonication for $10 \mathrm{sec}$ twice at $4^{\circ} \mathrm{C}$ (Matsushime et al., 1994). The heads with immunoprecipitated kinases obtained as described above were washed three times with lysis buffer, and twice in kinase buffer (50 mM HEPES, 
A.

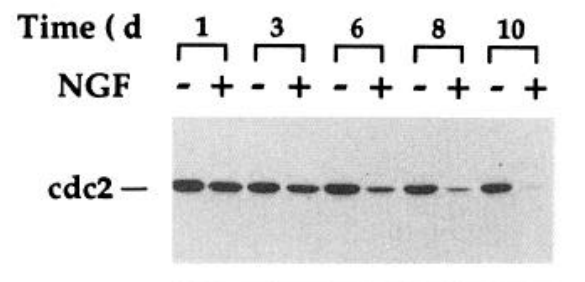

Figure 1. Expression of the cdc2-related proteins and cyclins in PC12 cells during NGF treatment. $A$, Expression of the cdc2-related proteins in $\mathrm{PC} 12$ cells. PC12 cells were plated, and cultured in the presence of NGF (lanes 1 , $3,5,7,9)$ and in the absence of NGF (lanes 2, 4, 6, 8, 10) for various lengths of time. Equal amounts of lysates from NGF treated and untreated PC12 cells ( $20 \mu \mathrm{g}$ protein/lane) were separated by $10 \%$ SDS-PAGE gels and transferred to nitrocellulose. The blots were probed, respectively, with cdc2, cdk2, cdk4, cdk5, and cdk6 antibodies. cdc2, cdk4, and cdk6 migrated at $34 \mathrm{kDa}$; both cdk2 and cdk 5 migated at $33 \mathrm{kDa}$. $B$, Expression of cyclins in PC12 cells. The analysis was the same as described in $A$, except that the blots were probed, respectively, with cyclin $\mathrm{A}, \mathrm{B} 1, \mathrm{D} 1, \mathrm{E}$, or PCNA antibodies. Cyclin A migrated at $60 \mathrm{kDa}$, cyclin $\mathrm{B} 1$ at $62 \mathrm{kDa}$, cyclin $\mathrm{D} 1$ at $36 \mathrm{kDa}$, cyclin $\mathrm{E}$ at $58 \mathrm{kDa}$, and PCNA at $37 \mathrm{kDa}$.
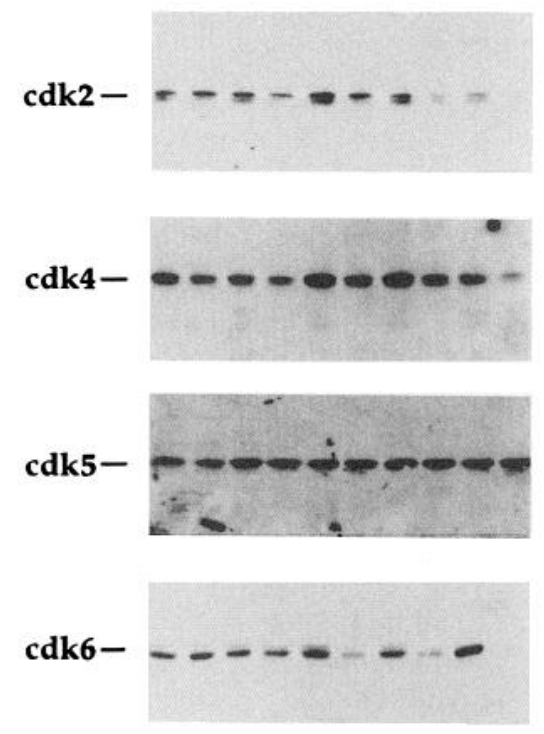

$\begin{array}{llllllllll}1 & 2 & 3 & 4 & 5 & 6 & 7 & 8 & 9 & 10\end{array}$
B.
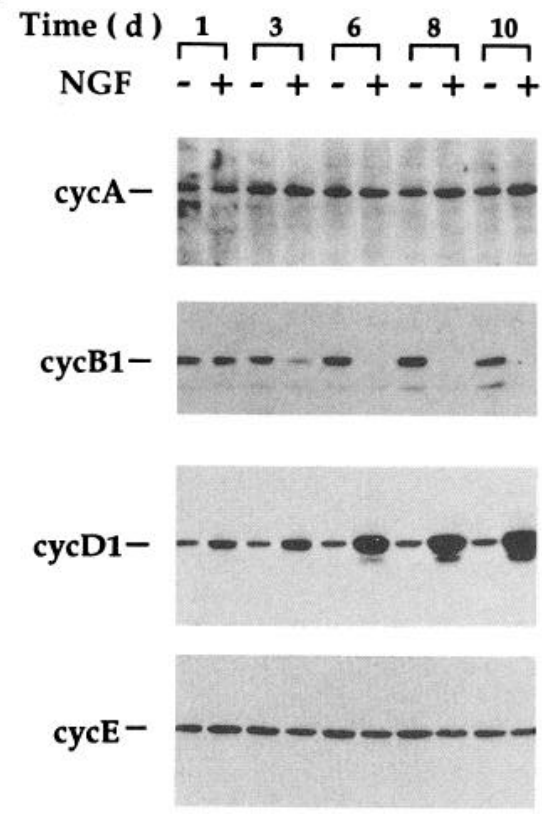

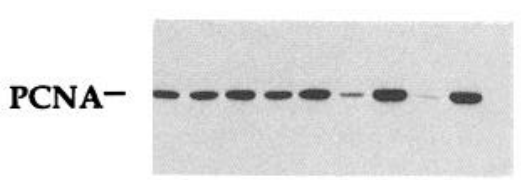

$\begin{array}{llllllllll}1 & 2 & 3 & 4 & 5 & 6 & 7 & 8 & 9 & 10\end{array}$
$\mathrm{pH} 7.5,10 \mathrm{~mm} \mathrm{MgCl}_{2}, 1 \mathrm{~mm}$ DTT). Kinase reactions were performed in kinase buffer with addition of $25 \mu \mathrm{M}$ unlabeled ATP, $10 \mu \mathrm{Ci}$ of $\gamma^{-32} \mathrm{P}$. ATP $(6000 \mathrm{Ci} / \mathrm{mmol}$, New England Nuclear), and kinase substrates at $30^{\circ} \mathrm{C}$ for $20 \mathrm{~min}$. The concentrations of substrates used in the kinase assays were $50 \mu \mathrm{g} / \mathrm{ml}$ for histone $\mathrm{H} 1$ (Boehringer Mannheim) or 10 $\mu \mathrm{g} / \mathrm{ml}$ for bacterially expressed GST-Rb fusion protein which contained amino acids 379-928 of Rb (Kaelin et al., 1991). The reactions were stopped by adding $2 \times$ Laemmli sample buffer. Phosphorylated histone $\mathrm{H} 1$ or GST-Rb proteins were resolved on $10 \%$ SDS-PAGE. Following electrophoresis, gels were fixed, dried, and exposed to Kodak XAR film.

Immunofluorescence assay. Cells growing on cover slips $\left(5 \times 10^{3}\right.$ cells/coverslip) were washed twice in PBS, and fixed for $10 \mathrm{~min}$ at RT in $4 \%$ paraformaldehyde/PBS/10 mM EGTA, and permeabilized for 5 min at RT in $0.2 \%$ Triton X-100 in PBS. Fixed and permeabilized cells were incubated with polyclonal cyclin D1 antibody (dilution 1:100 in TBST buffer $+3 \%$ BSA) for $2 \mathrm{hr}$ at $37^{\circ} \mathrm{C}$ in a humidified atmosphere, and then washed three times with PBS. Cell were then incubated with fluorescein isothiocyanate (FITC)-conjugated goat anti-rabbit IgG (dilution 1:200 in TBST+3\% BSA; Oncogene Science, Inc.) for $1 \mathrm{hr}$, with three washes in PBS in between. Coverslips were mounted onto the slides with Mowiol. Fluorescence was visualized under a Zeiss Axiophot microscope using a Neofluar $63 \times$ lens. Photographs were taken on Kodak TMax film.

Transfections and analysis of DNA content. 6-24 cells $\left(\sim 2 \times 10^{6}\right)$ were plated on collagen coated $10 \mathrm{~cm}$ dishes approximately $12 \mathrm{hr}$, and transfected with Rc-CMV or Rc-cycDl plasmid (provided by Dr. R. Weinberg) which contains the full cyclin D1 coding sequence (Ewen et al., 1993a), by high efficiency polycationic liposome transfection method (Hawley-Nelson et al., 1993). Briefly, $5 \mu \mathrm{g}$ of plasmid DNA in 0.5 $\mathrm{ml}$ of OPTI-MEM I medium (GIBCO-BRL, Inc.) was mixed with 40 $\mu \mathrm{l}$ of LipofectAMINE Reagent (GIBCO-BRL, Inc.) in $0.5 \mathrm{ml} \mathrm{OPTI-}$ MEM I medium, and incubated at room temperature for $30 \mathrm{~min}$ to allow DNA-liposome complexes to form; $3 \mathrm{ml}$ of OPTI-MEM I medium was added to the mixture, and then applied to cells. The cells were incubated for $6 \mathrm{hr}$ and replaced normal growth medium. For experiments involving NGF stimulation, transfection as above, NGF was added after 12 hr of removal of lipid-nucleic acid complexes. The cells were harvested after 24 or $42 \mathrm{hr}$ transfection for analysis of DNA content and Western blotting. The DNA content of individual nuclei analyzed by a BectonDickinson FACScan flow cytometer was as described by Buchkovich and Ziff (1994).

\section{Results}

The cdc2-related kinases and cyclins were differentially regulated by $N G F$

When asynchronous $\mathrm{PC} 12$ cells were cultured in the presence or absence of NGF, in agreement with previous reports, the cells slowed division and underwent neuronal differentiation (Burstein and Greene, 1982; Ignatius et al., 1985; Buchkovich and Ziff, 1994). Although after the first day of exposure to NGF only $10 \%$ of the cells extended neurites, by day 8 of NGF treatment, PC12 cells nearly reached a plateau of zero growth and almost all cells (95\%) bore fully extended neurites (data not shown).

To determine the effects of NGF on cell cycle regulatory components, we first examined the expression of the cdc2-related protein kinases in NGF treated and untreated PC12 cells. Total cell lysates were analyzed by Western blotting with antibodies to cdc2, cdk2, cdk4, cdk5, and cdk6. As shown in Figure $1 A$, the protein levels of $\mathrm{cdc} 2, \operatorname{cdk} 2$, and cdk6 gradually decreased following NGF treatment. There was a slight decrease in the protein levels of cdk4 in the NGF treated cells as compared to the untreated cells, which was observed in three parallel experiments and confirmed by Northern analysis. In contrast, protein levels of cdk5 remained constant throughout NGF treatment. These results demonstrate that exposure of PC12 cells to NGF leads to a downregulation of $\operatorname{cdc} 2$, cdk2, and cdk6, and a slight decrease of cdk4.

The cdc2-related protein kinases must associate with their cyclin partners in order to form active complexes capable of reg- 

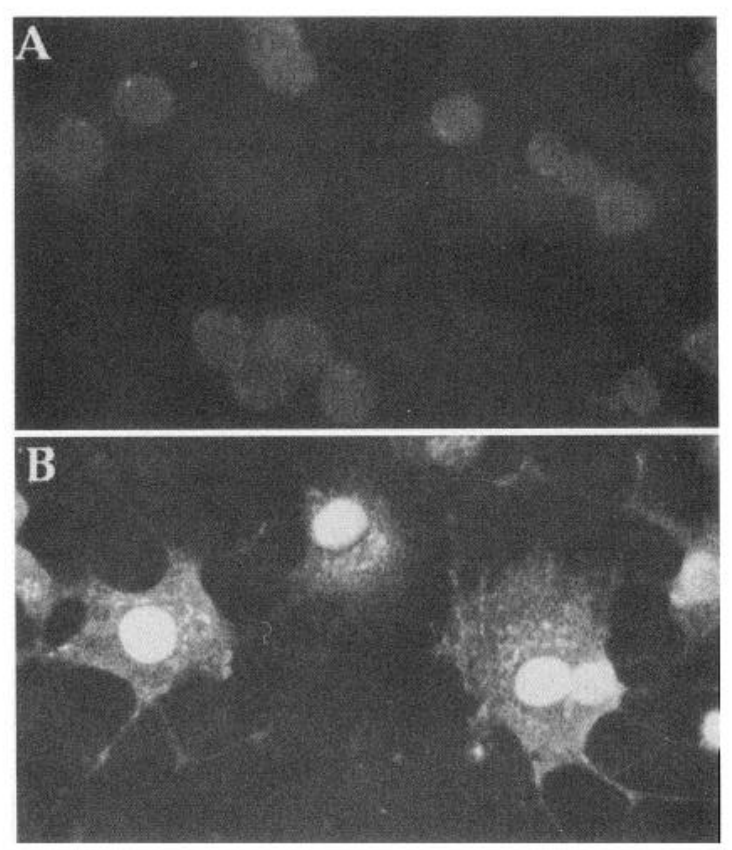

Figure 2. Accumulation of cyclin D1 in the nucleus in NGF-induced differentiated PC12 cells. PC12 cells treated with NGF for $8 \mathrm{~d}$ were fixed and stained with cyclin D1 antibodies to detect cyclin D1 using FITC-conjugated anti-rabbit antibodies. $A$, Immunofluorescence of cyclin D1 in NGF-untreated PC12 cells (top). B, Immunofluorescence of cyclin D1 in NGF-treated PC12 cells (bottom).

ulation of the cell cycle (Pines and Hunter, 1991). To determine the effects of NGF on the expression of cyclin proteins, we next analyzed cyclin protein levels in NGF treated and untreated PC12 cells by Western blotting as shown in Figure $1 B$. Cyclin proteins including cyclin $\mathrm{A}, \mathrm{B} 1, \mathrm{D} 1$, and $\mathrm{E}$ were detected in PC1 2 cells. NGF treatment had no effect on cyclin A and E protein levels. However, the levels of cyclin B1 protein greatly declined upon NGF treatment and cyclin B1 was absent at day 8. Additionally, NGF treatment led to a dramatic decrease and disappearance of the proliferating cell nuclear antigen (PCNA), a molecular indicator of cells in S phase (Bravo and MacdonaldBravo, 1987), as expected since cell proliferation decreases during PC12 cell differentiation. Conversely, cyclin D1 protein levels greatly increased upon NGF treatment and D1 reached its highest level at day 10 . This result was confirmed by using cyclin D1 antibodies from two different sources. On the other hand, little change of cyclin D2, which is expressed at low levels, was observed upon NGF treatment, and cyclin D3 was undetectable in both NGF treated and untreated PC12 cells under our assay conditions (data not shown). This indicates that D-type cyclins are expressed in a cell type specific manner in PC12. These observations suggest that NGF regulation of cyclin levels, including a strong decrease of cyclin B1 and a cell-type specific induction of cyclin D1, are involved in $\mathrm{PC} 12$ cell differentiation.

\section{Specific induction of cyclin D1 is associated with neuronal differentiation of $\mathrm{PC} 12$ cells}

Since induction of cyclin D1 during NGF-induced cell differentiation was unexpected, it was of interest to study this change in more detail. We used immunoflorescence assays to localize cyclin D1 in differentiated and undifferentiated PC12 cells. In asynchronously growing $\mathrm{PC} 12$ cells, a low immunoflorescent signal in both the cytoplasm and nucleus was detected (Fig. 2A).
Upon $8 \mathrm{~d}$ of NGF treatment, almost all of the cells exhibited the extension of neurites, and the cyclin D1 signal was detected at increased levels in the nucleus (Fig. $2 B$ ), in agreement with the finding that NGF induces a strong increase of cyclin D1 proteins in $\mathrm{PC} 12$ cells during differentiation. These results also suggest a functional role in the nucleus for cyclin D1 in differentiated PC12 cells.

Cyclin D1 was originally identified as a growth factor (CSF1) induced gene in mouse macrophage cell lines (Matsushime et al., 1991). Serum, PDGF, EGF, and bFGF also induced cyclin D1 in fibroblasts (Won et al., 1992; Sewing et al., 1993). We therefore asked if induction of cyclin D1 was NGF-specific or whether cyclin D1 was induced by other growth factors in PC12 cells. PC12 cells respond to NGF and FGF by differentiating, while these cells proliferate in response to EGF and insulin (Greene and Tischler, 1976; Schubert et al., 1978; Huff and Guroff, 1979, 1981). PC12 cells were treated with these growth factors for $8 \mathrm{~d}$. Protein levels of cyclin D1 and peripherin, a PC12 cell neuronal differentiation marker (Aletta et al., 1988; Parysek et al., 1987; Leonard et al., 1988; Gorham et al., 1990), were determined. Cyclin D1 and peripherin were greatly induced by the two differentiation factors, NGF and bFGF, but not by EGF or insulin in PC12 cells (Fig. 3A).

Although NGF and EGF have different effects on PC12 growth and cell fate, NGF and EGF activate several common pathways downstream from their receptors (Boonstra et al., 1983; Greenberg et al., 1985; Maher, 1988; Gizang-Ginsberg and Ziff, 1990; Chao, 1992). Thus, it was of interest to determine if EGF treatment could transiently affect expression of cyclin D1 in PC12 cells. PC12 cells were treated for various lengths of time with EGF. No significant differences in cyclin D1 protein levels were detected between EGF treated and untreated PC12 while D1 was induced by NGF treatment (Fig. 3B). Adenovirus-5 E1a transformed PC12 cells do not express NGF receptors and fail to differentiate in response to NGF (Boulukos and Ziff, 1993) and thus serve as a control. Two forms of cyclin D1 were detected in E1a transformed PC12 cells (Fig. $3 C$ ). Two cyclin D1 forms have been described previously (Matshushime et al., 1991, 1994), although the upper band seen here could be due to E1a PC12 cell protein cross-reactivity. Neither band was induced by NGF in E1a transformed PC12 cells. Taken together, we conclude that cyclin D1 is a specific target for NGF and FGF and that induction of cyclin D1 is associated with $\mathrm{PC} 12$ cell differentiation induced by these factors.

\section{Regulation of cyclin D1-associated complexes and their kinase activities by $N G F$}

To further reveal the functional role of the NGF-induced increase in cyclin D1 in PC12 cell differentiation, we assayed changes in the levels of complexes of cyclin D1 with the cdc2related kinases in response to NGF. PC12 cells were treated with NGF for $8 \mathrm{~d}$ and lysates from untreated or treated PC12 cells were immunoprecipited with antibodies to cdc2, cdk2, cdk4, cdk5, and cdk6, as well as cyclin D1, and the levels of kinaseassociated D1 were measured by immunoblotting using cyclin D1 antibody. As shown in Figure $4 A$, the overall levels of cyclin D1 once again showed a dramatic increase in NGF-treated PC12 cells (Fig. 4A, lanes 1-2). Very low levels of cyclin D1 were detected in cdk2 and cdk4 complexes in untreated PC12 cells (Fig. 4A, lanes 3 and 5) and these complexes increased upon NGF treatment (Fig. $4 A$, lanes 4 and 6). Cyclin D1 was also associated at low levels with cdc2 in NGF treated PC12 cells 
A.

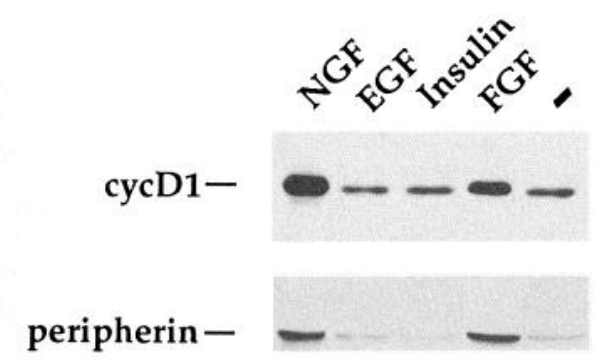

B.

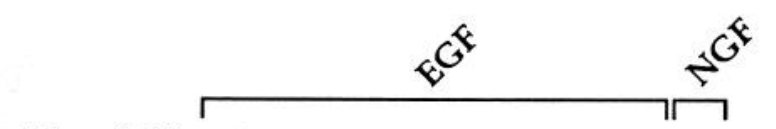

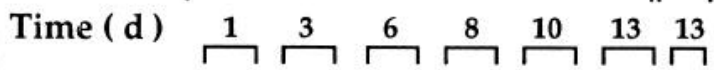
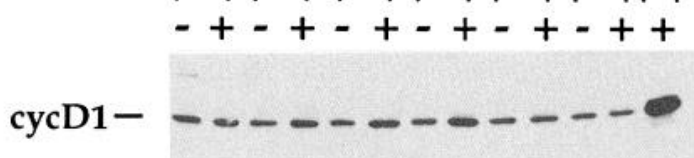

$\begin{array}{lllllllllll}1 & 2 & 3 & 4 & 5 & 6 & 7 & 8 & 9 & 10111213\end{array}$

C.

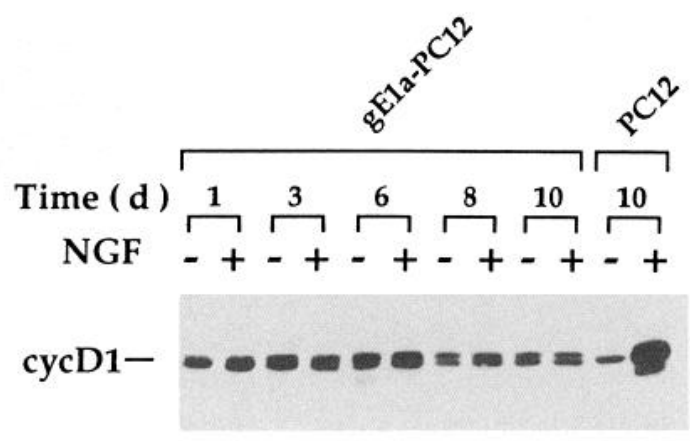

$\begin{array}{llllllllllll}1 & 2 & 3 & 4 & 5 & 6 & 7 & 8 & 9 & 10 & 11 & 12\end{array}$

Figure 3. Induction of cyclin D1 is specific for $\mathrm{PC} 12$ differentiation induced by NGF or FGF. $A$, Expression of cyclin D1 in response to growth factors. $\mathrm{PCl} 2$ cells were stimulated with $\mathrm{NGF}$ (lane I), or EGF (lane 2), or FGF (lane 4), or insulin (lane 3) or without any growth factors (lane 5) for $8 \mathrm{~d}$. Western blot analysis was carried out using cyclin D1 or peripherin antibodies as indicated. $B$, Expression of cyclin $\mathrm{D} 1$ in $\mathrm{PC} 12$ cells during EGF treatment. Lysates from PC12 cells untreated (lanes 1, 3, 5, 7, 9, 11) or treated (lanes 2, 4, 6, 8, 10, 12) with EGF for various lengths of time, or treated with NGF (lane 13) for 13 d were analyzed by Western blotting using cyclin D1 antibodies. $C$, Expression of cyclin D1 in E1a-transformed-PC12 cells during NGF treatment. Lysates from NGF treated (lanes 2, 4, 6, 8, 10), and NGF untreated (lanes $1,3,5,7,9)$ gEla-PC12 cells, or NGF treated (lane 12), and NGF untreated (lane 11) PC12 cells were analyzed as described in $B$.

but this association was undetectable in untreated PC12 cells (Fig. 4A, lanes 9-10). No cyclin D1 complexes with cdk5 and cdk6 were detected in either NGF treated or untreated PC12 cells (Fig. 4A, lanes 7-8 and 11-12). Reciprocal experiments in which immunoprecipitation with antibodies to $\mathrm{cdk} 2, \mathrm{cdk} 4, \mathrm{cdc} 2$, cdk5, cdk6, and cyclin D1, was followed by immunoblotting analysis using antibodies to cdk2, cdk4, cdc2, cdk5, and cdk6, were also carried out. This analysis verified that cdk2/D1 and cdk4/D1 complexes increased upon NGF treatment, even though NGF treatment led to a reduction of the protein levels of cdk2 and cdk4 (Fig. 4B,C). No cyclin D1 associated complexes with cdk5 and cdk6 were detected in either NGF treated or untreated PC12 cells (data not shown). Cyclin D1/cdc2 complexes were only present at very low levels in NGF treated PC12 cells (data not shown). These results demonstrate that induction of cyclin D1 is correlated with increases of D1/cdk2 and D1/cdk4 complexes in NGF-induced differentiated cells.

While we have shown that NGF exerts specific effects on the levels of cyclin D1, the cdc2-related proteins, and cyclin D1/the cdc2-related protein complexes, it was also important to determine whether these NGF-regulated cyclin D1 complexes exhibit kinase activity. Antibodies can selectively immunoprecipitate these cdc2-related kinases along with their regulatory cyclin subunits. These immune complexes can then be assayed for their ability to phosphorylate an exogenous substrate, such as histone $\mathrm{H} 1$ or the retinoblastoma protein $(\mathrm{Rb})$. NGF treated and untreated PC12 cells on day 8 were chosen for analysis because the effects of NGF on cell proliferation and neurite growth peak over $8 \mathrm{~d}$ of NGF treatment. Cell lysates were immunoprecipitated with antibodies to the cdc2-related proteins. The kinase activities of immune complexes were detected by using histone $\mathrm{H} 1$ or GST-Rb as a substrate in vitro.

When histone $\mathrm{H} 1$ was used as a substrate, histone $\mathrm{H} 1$ kinase activity was detected in $\alpha$-cdc 2 and $\alpha$-cdk 2 immunoprecipitates of lysates from NGF treated and untreated cells (Fig. 5A, lanes 11-12 and 5-6). These activities decreased after exposure to NGF in parallel with the decreases of the protein levels of cdc2 and $c d k 2$, with $c d k 2$ showing a greater decrease than cdc 2 . However, little activity above background was detected in either NGF treated or untreated PC12 lysates for cdk4 or cdk5 or cdk6 using this assay (Fig. 5A, lanes 7-8, 9-10, and 3-4). Interestingly, histone $\mathrm{H} 1$ kinase activities of cyclin D1 immune complexes decreased in NGF treated cells (Fig. 5A, lanes 1-2). Similarly, the histone $\mathrm{H} 1$ kinase activities of cyclin $\mathrm{A}, \mathrm{B} 1$, and $\mathrm{E}$ immune complexes also decreased in NGF treated cells (data not shown).

The retinoblastoma protein is phosphorylated by one or more cdk kinases in a cell cycle dependent manner (Lin et al., 1991; Akiyama et al., 1992; Matsushime et al., 1994; Meyerson et al., 1994). When GST-Rb was used as a substrate, cdc2 and cdk2 immune complexes were also shown to be the two strong kinase activities in lysates from PC12 cells (Fig. 5B, lanes 11 and 7). NGF treatment reduced cdk2 kinase activity much more greatly than cdc2 kinase activity (Fig. $5 B$, lanes $7-8$ and 11-12), as seen previously with the histone $\mathrm{H} 1$ assay. Comparatively low levels of $\mathrm{Rb}$ kinase activities of cdk4 and cdk6 immune complexes were detected and these decreased slightly (Fig. $5 B$, lanes 5-6 and 3-4). The lower activity of cdk5 remained unchanged by NGF treatment (Fig. 5B, lanes 9-10). Quantitation by densitometric scanning of the kinase assay autoradiograms showed that cdk2 kinase activity was at least 50 -fold higher than cdk4 kinase activity in untreated cells, and cdk2 and cdk4 kinase activities are comparable in NGF treated PC12 cells. Rb kinase activities of cyclin D1 immune complexes were also decreased by NGF (Fig. $5 B$, lanes 1-2). This inhibition of cyclin D1-associated kinase activities by NGF is very novel since NGF treatment leads to increases of D1/cdk2, D1/cdk4, and D1/cdc2 complexes as shown in Figure 4. These observations suggest that 
A.

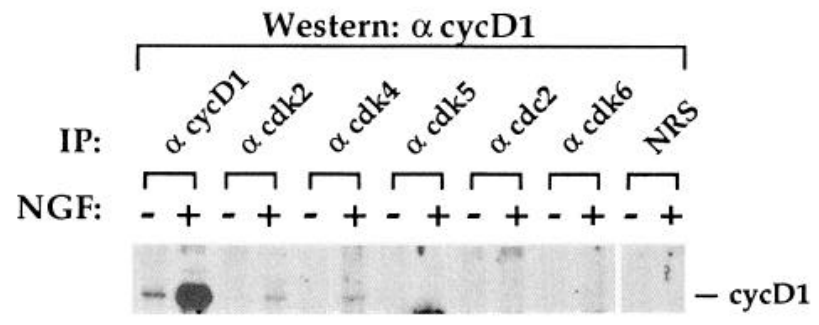

$\begin{array}{lllllllllllllll}1 & 2 & 3 & 4 & 5 & 6 & 7 & 8 & 9 & 10 & 11 & 12 & 13 & 14\end{array}$
B.

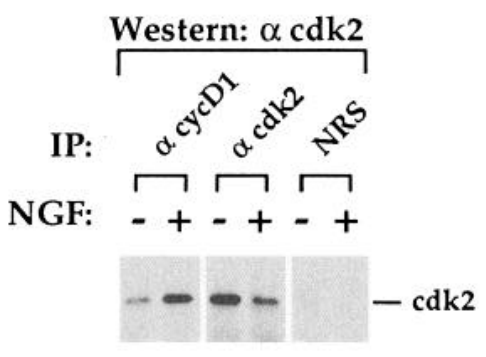

$\begin{array}{llllll}1 & 2 & 3 & 4 & 5 & 6\end{array}$
C.

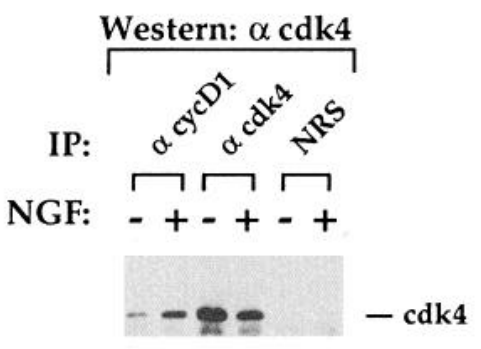

$\begin{array}{llllll}1 & 2 & 3 & 4 & 5 & 6\end{array}$
Figure 4. Association of cyclin D with the cdc2-related kinases upon NGF treatment. The immune complexes from PC12 cell lysates untreated or treated with NGF for $8 \mathrm{~d}$ were obtained by immunoprecipitation, and analyzed by Western blotting (see Materials and Methods). A, cyclin D1-associated complexes in response to NGF. Immunoprecipitations with cyclin D1 (lanes 1-2), cdk2 (lanes 3-4), cdk4 (lanes 56 ), cdk5 (lanes 7-8), cdk6 (lanes 1112 ), cdc2 (lanes 9-10) antibodies, or NRS (lanes 13-14) were analyzed by Western blotting using cyclin D1 antibody. Cells in lanes $1,3,5,7,9,11$, 13 were untreated with NGF. Cells in lanes $2,4,6,8,10,12,14$ were treated with NGF. $B$, Immunoprecipitation with cyclin D1 (lanes 1-2), cdk2 (lanes 3-4) antibodies, or NRS (lanes 5-6) followed by Western blot analysis using cdk2 antibody. $C$, Immunoprecipitation with cyclin D1 (lanes 1-2), cdk4 (lanes 3-4) antibodies, or NRS (lanes 5-6) followed by Western blot analysis using cdk4 antibody. the increase in D1/cdk2, D1/cdk4, and D1/cdc2 complexes in NGF treated PC12 cells is accompanied by the onset of an inhibitory mechanism that contributes to an overall decrease of cyclin D1-associated kinase activities.

There are several indications that $\mathrm{p} 21$, an inhibitor of cyclindependent kinases, has a role in negative regulation of the cell cycle in G1 phase. The p 21 protein can inhibit the kinase activity of various cyclin-cdk complexes. To determine whether p21 expression changed during PC12 cell differentiation, we examined p21 levels following NGF treatment. Western blot analysis of the lysates from cells after various times of NGF treatment or from untreated $\mathrm{PC} 12$ cells showed that $\mathrm{p} 21$ protein levels were increased during NGF treatment (Fig. 6A). This suggests that upregulation of p21 may play a role in inhibition of cell proliferation during $\mathrm{PC} 12$ cell differentiation. Since cyclin D1 associated kinase activities declined during NGF treatment we next asked whether p21 was associated with cyclin D1 in response to NGF. To do this, PC12 cells were treated or left untreated with NGF for $8 \mathrm{~d}$ and lysates were immunoprecipited with antibodies to p21, and the levels of cyclin D1 were measured by immunoblotting using cyclin D1 antibody. Cyclin D1/p21 complexes were undetectable in NGF untreated PC12 cells, however, these complexes increased in NGF treated PC12 cells (Fig. 6B, lanes 1 and 2). Consistent with this result, we were also able to detect the increase of p21 in anti-cyclin D1 precipitates upon NGF treatment (Fig. $6 C$, lane 4). These results demonstrate that the inhibitor, p21, accumulates in PC12 cells and enters complexes containing cyclin D1 at times when D1 associated kinase activity declines. This decline takes place although the absolute levels of cyclin Dl-cdk complexes increase. This suggests that p21 contributes to a reduction of cyclin D1-associated kinase activities in NGF treated PC12 cells and that this change is induced by NGF.

Increase of $D I / R b$ complexes is correlated with accumulation of unphosphorylated $R b$ upon NGF treatment

$\mathrm{Rb}$ protein functions as a negative regulator of cell proliferation, and its activity appears to be modulated by phosphorylation. Previous work has shown that unphosphorylated $\mathrm{Rb}$ which is isolated from cells in the G0 and G1 phases of the cell cycle, migrates at molecular mass of $105 \mathrm{kDa}$, while phosphorylated $\mathrm{Rb}$ which is isolated from the $\mathrm{S}, \mathrm{G} 2$, and $\mathrm{M}$ phases, migrates at molecular mass of 110-112 kDa. We next investigated whether NGF affected the expression and phosphorylation of Rb protein. The total pool of $\mathrm{Rb}$ was visualized by immunoblotting analysis of whole-cell extracts using antibody to $\mathrm{Rb}$. PC12 cells grown asynchronously showed mainly phosphorylated $\mathrm{Rb}$ proteins which migrated as multiple bands at the molecular mass range of 110-112 kDa (Fig. $7 A$ ). In agreement with a previous report (Kalman et al., 1993), as early as $1 \mathrm{~d}$ after addition of NGF, unphosphorylated $\mathrm{Rb}$ species appeared at the molecular mass of $105 \mathrm{kDa}$. However, $\mathrm{Rb}$ protein levels underwent little change in response to NGF (Fig. 7A). ${ }^{32} \mathrm{P}$-orthophosphate labeled $\mathrm{PC} 12$ cells exhibited phosphorylated Rb in NGF-untreated PC12 cells, but not in NGF-treated PC12 cells (Fig. $7 B$ ), indicating a decrease in phosphorylation of Rb with NGF treatment. Figure $7 A$ clearly shows that the band of dephosphorylated $\mathrm{Rb}$ is greater in the NGF treated cells than untreated cells at any given time of treatment. Furthermore, the level of phosphate labeled Rb in treated cells relative to untreated control (Fig. $7 B$ ) shows that the rate of phosphorylation of Rb declines with NGF treatment. 
A.

Figure 5. Effect of NGF on cyclinassociated kinases and the cdc2-related kinase activities. Lysates from $\mathrm{PC} 12$ cells untreated (lanes 1, 3, 5, 7, 9, 11, 13 ) or treated (lanes 2, 4, 6, 8, 10, 12, 14) with NGF for $8 \mathrm{~d}$ were immunoprecipitate with antibody. The immune complexes were mixed with $\gamma-{ }^{32} \mathrm{P}$-ATP and histone $\mathrm{H} 1$, or GST-Rb for in vitro kinase assays. Phosphorylated histone H1 or GST-Rb proteins were separated from unincorporated $\gamma{ }^{3}{ }^{32} \mathrm{P}$-ATP on a SDS-PAGE gel. A, Histone $\mathrm{Hl}$ kinase activities of the cdc2-related kinases. Lysates were immunoprecipitated individually with cyclin D1 (lanes 1-2), cdc2 (lanes 11-12), cdk2 (lanes 5-6), cdk4 (lanes 7-8), cdk5 (lanes 9-10), cdk6 (lanes 3-4) antibodies, or normal rabbit sera (NRS) (lanes 13-14). Double bands of phosphorylated histone $\mathrm{H} 1$ with molecular mass around 33 kDa were detected by autoradiography. The exposure time was $2 \mathrm{hr}$. B, GST$\mathrm{Rb}$ kinase activities of the cdc2-related kinases. Lysates were immunoprecipitated individually with cyclin D1 (lanes 1-2), cdc2 (lanes 11-12), cdk2 (lanes 7-8), cdk4 (lanes 5-6), cdk5 (lanes 910), cdk6 (lanes 3-4) antibodies, or normal rabbit sera (NRS) (lanes 1314). Phosphorylated GST-Rb with molecular mass about 80-90 kDa was detected by autoradiography. The exposure time was $6 \mathrm{hr}$.
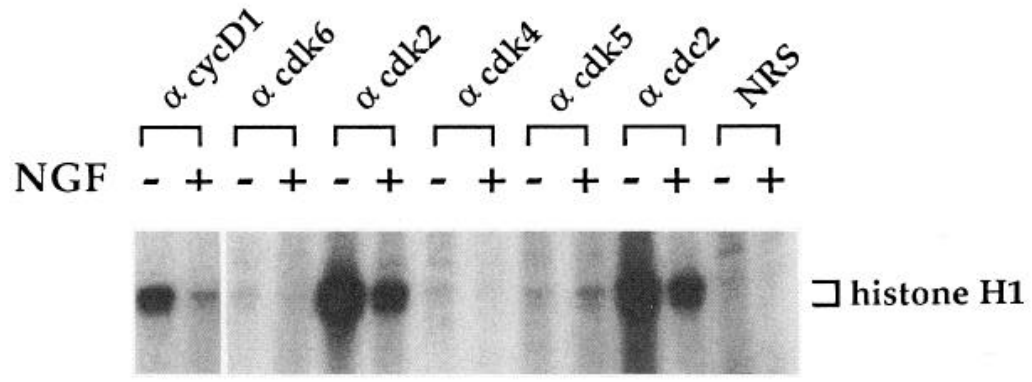

$\begin{array}{llllllllllllll}1 & 2 & 3 & 4 & 5 & 6 & 7 & 8 & 9 & 10 & 11 & 12 & 13 & 14\end{array}$

B.

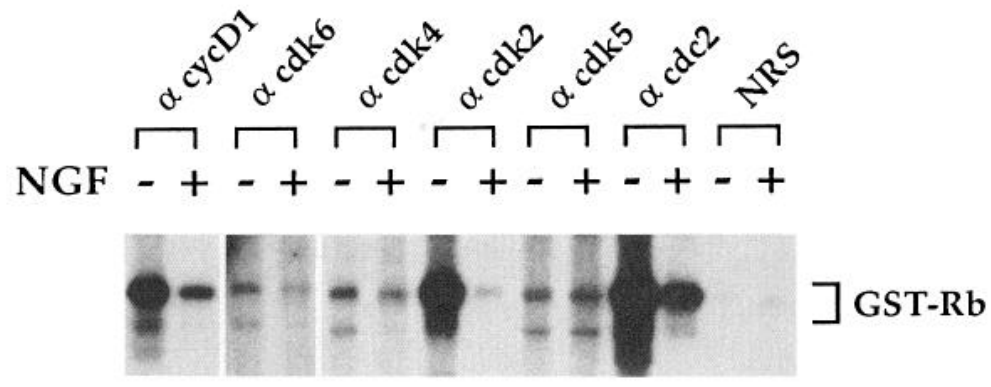

$\begin{array}{llllllllllllll}1 & 2 & 3 & 4 & 5 & 6 & 7 & 8 & 9 & 10 & 11 & 12 & 13 & 14\end{array}$
Our results provide evidence that NGF leads to the accumulation of a dephosphorylated or hypophosphorylated form of Rb.

Cyclin D1 can directly bind to Rb in vitro and in vivo (Dowdy et al., 1993). Hypophosphorylated Rb associates with cyclin D1 while the hyperphosphorylated forms are unable to do so (Dowdy et al., 1993). Since NGF caused an increase of cyclin D1 and accumulation of unphosphorylated $\mathrm{Rb}$, we next asked whether cyclin D1 could form the complexes with Rb in NGF untreated and treated PC12 cells. To detect association of cyclin D1 with $\mathrm{Rb}$ in vivo, immunoprecipitation of lysates with antibody to $\mathrm{Rb}$ following immunoblotting using antibody to cyclin D1 was carried out. D1/Rb complexes were not detected in NGF-untreated PC12 cells (Fig. 7C, lane 3). However, a dramatic increase of
$\mathrm{D} 1 / \mathrm{Rb}$ complexes in NGF treated PC12 cells was observed (Fig. $7 C$, lane 4 ). In a control, immunoprecipitation of $\mathrm{Dl} / \mathrm{Rb}$ complexes with antibody to $\mathrm{Rb}$ was blocked by a control peptide (Fig. 7C, lane 2). These results indicate that an increase of $\mathrm{Rb} /$ D1 complexes was correlated with induction of cyclin D1 and accumulation of unphosphorylated $\mathrm{Rb}$ during NGF-induced PC12 cell differentiation.

\section{Overexpression of cyclin D1 arrested cells in G1 and inhibited PCNA expression}

To understand the role of cyclin D1 in NGF-induced differentiation of PC12 cells, we determined if overexpression of cyclin D1 could arrest cell cycle progression and induce the differen-

Figure 6. Increase of expression of p21 and cyclin D1/p21 complexes during NGF treatment. A, Expression of p21 in PC12 cells during NGF treatment. The analysis was the same as described in Figure $1 A$, except that the blots were probed with p21 antibody. p21 migrated at $21 \mathrm{kDa}$. $B$, Increase of cyclin D1/p21 complexes upon NGF treatment. Immunoprecipitation with p21 (lanes 1-2), cyclin D1 (lanes 3-4) antibodies, or NRS (lanes 5-6) followed by Western blot analysis using cyclin D1 antibody. C. Increase of p21/cyclin D1 complexes upon NGF treatment. Immunoprecipitation with p21 (lanes 1-2), cyclin D1 (lanes 3-4) antibodies, or NRS (lanes 5-6 followed by Western blot analysis using p21 antibody.

Figure 7. Accumulation of unphosphorylated $\mathrm{Rb}$ and increase of cyclin D1/Rb complexes in NGF treated PC12 cells. A, Accumulation of unphosphorylated $\mathrm{Rb}$ during NGF treatment. The analysis was the same as described in Figure $1 A$, except that the blots were probed with Rb antibody. $\mathrm{Rb}^{\text {phos }}$ indicates as phosphorylated $\mathrm{Rb}$, which migrated at $110-112 \mathrm{kDa}$. Rb indicates as unphosphorylated $\mathrm{Rb}$ which migrated at $105 \mathrm{kDa}$. $B$, Phosphorylation of $\mathrm{Rb}$ in NGF treated or untreated $\mathrm{PC} 12$ cells. PC12 cells pretreated with or without NGF for $8 \mathrm{~d}$ were incubated with ${ }^{32} \mathrm{P}$ orthophosphate for $4 \mathrm{hr}$. Lysates were immunoprecipitated with a monoclonal antibody to $\mathrm{Rb}$ (XZ133). The immunoprecipitates were seperated on 7.5\% SDS-PAGE gel. Phosphorylated Rb with apparent molecular mass of about $110 \mathrm{kDa}$ was detected by autoradiography. The exposure time was $12 \mathrm{hr}$. $C$, Increase of cyclin D1/Rb complexes in NGF treated PC12 cells. Immunoprecipitation with $\alpha$-Rb + control peptide (Santa Cruz Biotechnology, Inc., sc-50P) (lanes 1-2), $\alpha$-Rb (lanes 3-4), $\alpha$-cyclin D1 (lane 5-6) antibodies, or NRS (lanes 7-8) followed by Western blot analysis using $\alpha-\mathrm{Rb}$ antibody. 
A.

$$
\begin{aligned}
& \text { Time (d) } 1 \text { r } \\
& \text { NGF }-+\cdot++\cdot++ \\
& \text { - - - - - p } 21 \\
& \begin{array}{llllllllll}
1 & 2 & 3 & 4 & 5 & 6 & 7 & 8 & 9 & 10
\end{array}
\end{aligned}
$$

B.

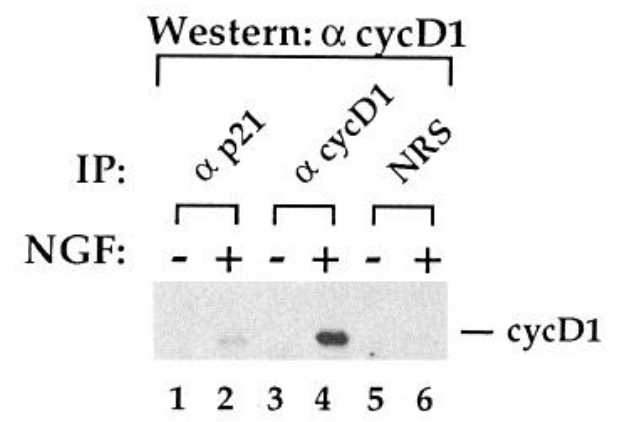

C.

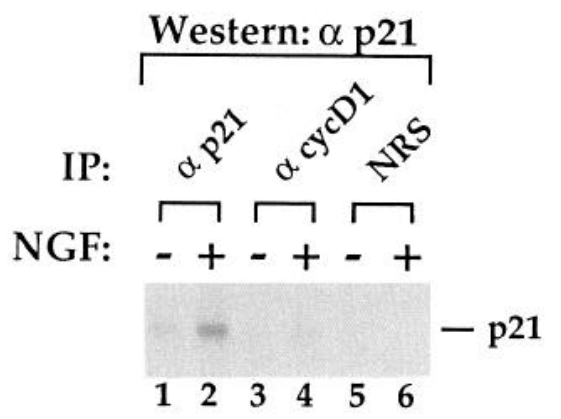

A.

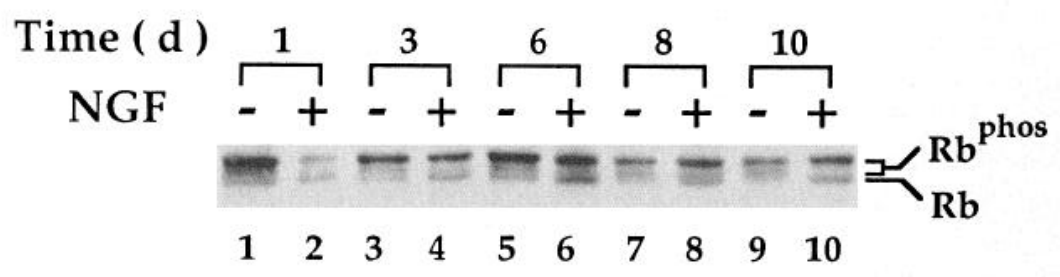

B.

C.

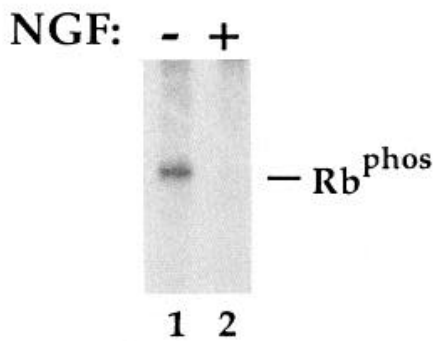

12

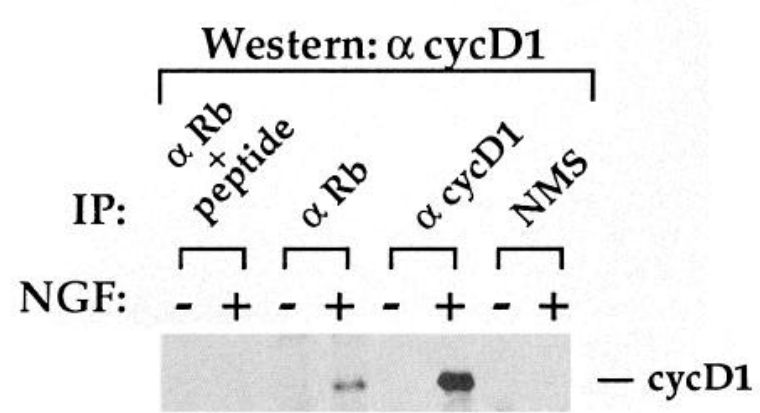

$\begin{array}{llllllll}1 & 2 & 3 & 4 & 5 & 6 & 7 & 8\end{array}$ 

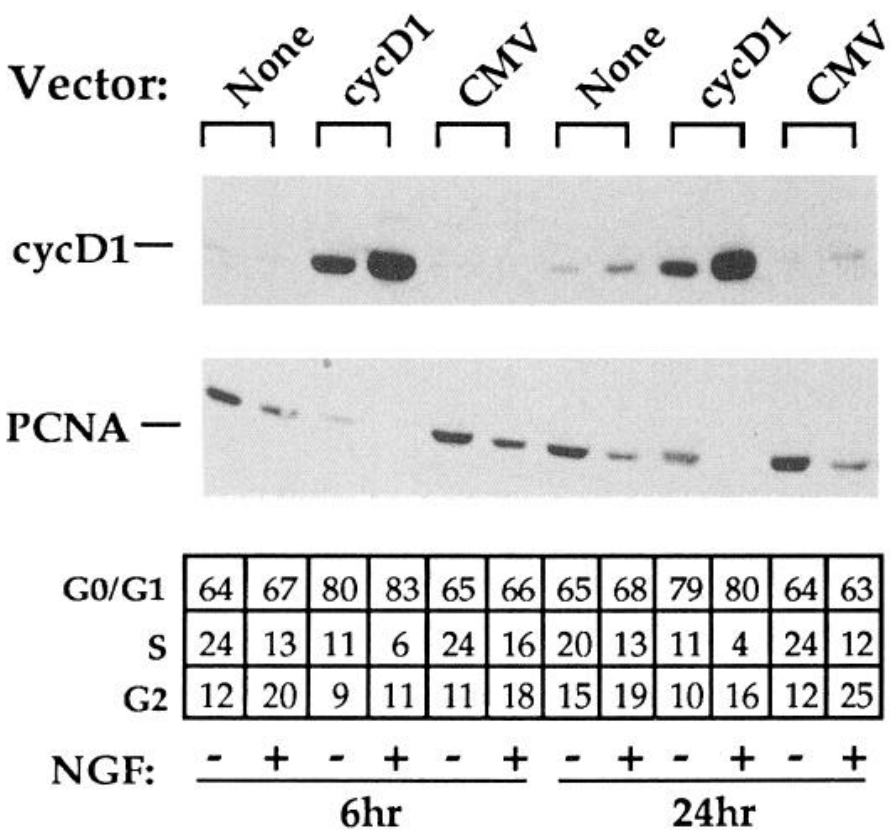

Figure 8. Overexpression of cyclin D1 in 6-24 cells alters the cell cycle phase distribution and expression of PCNA. 6-24 cells, which overexpress the trk NGF receptor and differentiate with accelerated kinetics upon NGF treatment were transfected with Rc-CMV or Rc-cycD1 plasmid or were left untransfected, and incubated with or without NGF at indicated times before lysis of cells. Nuclei were isolated from lysates, and stained with propidium iodide, and analyzed for the protein levels by Western blotting using antibodies to cyclin D1 (top) and PCNA (center panel). The cell cycle profile (percentages) at G0/G1 phase (2n), S phase (3n), G2 phase (4n) for DNA content determined by flow cytometry are shown (bottom). The G2/M phase may only reflect cells in G2 from this population due to break down the nuclear envelope of cells during M phase (Murray and Hunt, 1993; Buchkovich and Ziff, 1994).

tiation of PC12 into neuron-like cells. It has been noted that cyclin D1 is expressed in postmitotic neurons (Freeman et al., 1994). Also, it has been difficult to obtain stable clonal cell lines overexpressing D cyclin, since the exclusion of cyclin D1 from the nucleus and/or its degradation are required for progression into S phase (Baldin et al., 1993; Quelle et al., 1993). Thus we employed transient expression of cyclin D1. Full PC12 cell differentiation induced by NGF requires about $8 \mathrm{~d}$. To achieve more rapid differentiation, we employed a clonal PC12 cell line, $6-24$, that has been stably transfected with the gene encoding the trk NGF receptor and which differentiates with accelerated kinetics relative to the parental PC12 cells (Hempstead et al., 1992). After $6 \mathrm{hr}$ exposure to NGF, $75 \%$ of $6-24$ cells extended neurites, and almost all cells fully extended neurites following NGF treatment for $24 \mathrm{hr}$. To study the effects of cyclin Dl on the PC12 cell differentiation state, a mammalian expression plasmid containing the full-length cyclin D1 cDNA was transiently expressed in these cells by the lipofection technique. As a control for the transfection efficiency, in a separate experiment we transfected 6-24 cells with a vector expressing $\beta$-galactosidase from the CMV promoter and assayed expression in situ by $\mathrm{X}$-Gal staining. We observed that $\beta$-galactosidase was expressed in $60-70 \%$ of the cells indicating high efficiency transfection (data not shown). The efficiency of expression of the transfected cyclin D1 expression plasmid was confirmed by Western blotting with antibody to cyclin Dl (Fig. 8). Overexpression of cyclin D1 did not cause 6-24 cells to extend neurites within 3 d, and similar results were found in $\mathrm{PC} 12$ cells which overexpressed cyclin D1 (data not shown), suggesting that cyclin D1 on its own does not activate the signaling pathway induced by NGF which leads to PC12 cell morphological differentiation. The results of Figure 8 show that NGF induced the levels of cyclin D1 only 2-3-fold after $24 \mathrm{hr}$ treatment in 6-24 cells, an amount which is similar to PC12 cells (Fig. $1 B$ ), while at that time, these cells are fully differentiated by NGF. These observation suggested that although 6-24 cells might differentiate more rapidly, they do not respond morphologically more rapidly to one factor downstream from the trk NGF receptor, cyclin D1.

To test whether overexpression of cyclin D1 affected the cell cycle phase distribution of 6-24 cells, these cells at 24 or $42 \mathrm{hr}$ after cyclin D1 expression vector transfection were analyzed for DNA content. Nuclei were isolated from cells that had been treated or untreated with NGF for $6 \mathrm{hr}$ or $24 \mathrm{hr}$. The nuclei were stained with propidium iodide, and then analyzed by flow cytometry. The results are shown in Figure 8. In control cells, untransfected or transfected with vector alone after $24 \mathrm{hr}$, about $62-$ $64 \%$ of the cells were in G1 phase. In contrast, $80 \%$ of the cells transfected with the cyclin D1 expression vector for $24 \mathrm{hr}$ were in G1 phase. Moreover, a decrease of $60 \%$ in the number of S phase cells, and a decrease of $30 \%$ in the number of G2 phase cells was observed in the cell population transfected with cyclin D1 compared with the population of untransfected or transfected with vector alone. Similar results of overexpression of cyclin D1 were found following analysis of DNA content after $42 \mathrm{hr}$ of transfection. Thus, cyclin D1 could arrest cells in G1 phase and obstruct cell entry into $S$ phase. However, an accumulation of G2 phase cells, a decrease of $\mathrm{S}$ phase cells and a small increase or little change of G1 phase cells were observed in the presence of NGF relative to the absence of NGF for $6 \mathrm{hr}$ or $24 \mathrm{hr}$. These data are very similar to the data reported by others in PC12 cells (Ignatius et al., 1985; Buchkovich and Ziff, 1994).

Cyclin D1 can block PCNA relocation to the nucleus, and thus inhibit DNA replication and repair (Pagano et al., 1994). The results described above (Fig. $1 B$ ), showing the induction of cyclin D1 and the concomitant disappearance of expression of PCNA during NGF-induced PC12 cell differentiation prompted us to examine whether overexpression of cyclin D1 affected expression of PCNA. For this purpose, the 6-24 cells which were transfected with a cyclin D1 expression vector were analyzed after 24 or 42 hr by Western blotting with antibody to PCNA. As before, the protein levels of PCNA were reduced in the presence of NGF (Fig. 8). Overexpression of cyclin Dl also caused a decrease of PCNA (Fig. 8) and did not change the p21 protein levels (data not shown) in the absence of NGF. However, overexpression of cyclin D1 and treatment of NGF together showed a very strong, synergistic inhibition of PCNA expression (Fig. 8). This finding implies that cyclin D1 may mediate inhibition of DNA replication and repair via repression of expression of PCNA.

\section{Discussion}

We have shown that during NGF-induced differentiation of PC12 cells, NGF specifically regulates the expression and kinase activities of the cdc2-related kinases and their regulatory subunits, the cyclins. Of the five cdc2-related proteins expressed in $\mathrm{PC} 12$ cells, with the exception of cdk5, the protein levels and the enzymatic activities of each cdc2-related protein decreased during NGF-induced differentiation. NGF induction of the cdk inhibitory protein, p21, provides an additional mechanism for NGF-specific repression of cdk kinase activity. These reductions in the levels and the 
kinase activities of the cdc2-related proteins demonstrate that NGF induces profound changes in the cell cycle regulatory machinery which may account for the withdrawal from cell cycling of NGF-responsive neurons during terminal differentiation. While all cyclins (with the exception of D3) were expressed in $\mathrm{PC} 12$ cells with $\mathrm{D} 2$ at low levels, different patterns of change following NGF treatment were found. Perhaps the three most striking observations in response to NGF treatment were (1) the dramatic, differentiation-specific induction of cyclin D1, (2) the reduction of the cyclin D1-associated kinase activities, possibly through induction of the cdk kinase inhibitor, p21 (this reduction occurred despite an increase in the absolute levels of the cyclin-kinase protein); (3) the accumulation of unphosphorylated $\mathrm{Rb}$ and the increase of $\mathrm{D} 1 / \mathrm{Rb}$ complexes. Finally, we demonstrate that cyclin D1 can cause cells to arrest in Gl phase, prevent entry into $S$ phase, and inhibit expression of PCNA.

The cdc2-related kinases are indispensable for cell cycle progression in all multicellular eukaryotes, and their levels remain relatively constant through the cell cycle in proliferating cells (Draetta and Beach, 1988; Marraccino et al., 1992; Rosenblatt et al., 1992; Tsai et al., 1993a). The observation in this report of the suppression of $\operatorname{cdc} 2, \operatorname{cdk} 2$, and cdk6 levels, and to a lesser extent cdk4 (see Fig. 1), by NGF during PC12 differentiation raises the question of whether downregulation of the cdc2-related proteins is the basis for NGF-induced PC12 withdrawal from the cell cycle. Other observations that downregulation of the cdc2-related protein levels is associated with neuronal differentiation were previously reported. Fully differentiated sympathetic neurons of the rat superior cervical ganglia did not express cdk2 and cdc2, while the cells expressed other cdks (Freeman et al., 1994). In the developing CNS, cde2 mRNA was downregulated, concomitant with the cessation of cell proliferation in the CNS (Hayes et al., 1991; Okano et al., 1993). This suggests that downregulation of $\mathrm{cdk} 2$ and $\mathrm{cdc} 2$ protein levels is correlated with the terminal differentiation of neurons, and probably cell cycle arrest also. In agreement, complexes of cdk2/ cyclin A with the Rb-related protein, p107 and the transcription factor E2F were downregulated in PC12 cells by NGF (Buchkovich and Ziff, 1994). Moreover, the expression and function of the cdc2-related proteins have been characterized in systems other than differentiating neurons. TGF- $\beta 1$, which inhibits cell proliferation, suppresses cdk4 synthesis in G1 phase in mink lung epithelial cells while constitutive cdk4 synthesis in these cells leads to TGF- $\beta 1$ resistance (Ewen et al., 1993b). This suggests that downregulation of cdk4 synthesis contributes to TGF$\beta 1$-mediated cell cycle arrest. Similarly, regulation of the cdc2related proteins may constitute a basis for a NGF mechanism for G1 growth arrest.

It has been reported that cdk 5 was only expressed in terminally differentiated neurons, not in the proliferating cells of the nervous system, and that the expression and activity of cdk5 increased progressively as increasing numbers of cells exited the proliferative cycle (Tsai et al., 1993b). The persistent levels of cdk5 protein after NGF treatment in PC12 cells observed here suggest that cdk5 could play a functional role either in the process of PC12 differentiation or in postdifferentiation functions. Our failure to detect any change in cdk5-associated kinase activity toward histone $\mathrm{Hl}$ and $\mathrm{Rb}$ in NGF treated and untreated PC12 may be due to specificity of $\mathrm{cdk} 5$ for phosphorylation of protein substrates other than histone $\mathrm{H} 1$ or $\mathrm{Rb}$ in $\mathrm{PC} 12$ cells. Indeed, cdk 5 has been purified as a brain neurofilament kinase (Lew et al., 1992a,b).
It is well established that the activity of the cdc2-related kinases is dependent upon both kinase binding to cyclin regulatory subunits and upon phosphorylation and dephosphorylation of the kinase itself. Downregulation of $\mathrm{cdc} 2, \mathrm{cdk} 2, \mathrm{cdk} 4$, and $\mathrm{cdk} 6$ kinase activities by NGF observed here in part results from NGF suppression of $\mathrm{cdc} 2, \mathrm{cdk} 2, \mathrm{cdk} 4$, and $\operatorname{cdk} 6$ protein levels. The decrease of cyclin $\mathrm{B} 1$ protein levels induced by NGF can also partially account for the decrease of $\mathrm{cdc} 2$ kinase activities since cyclin $\mathrm{B} 1$ is a regulatory subunit of $\mathrm{cdc} 2$. In addition, other mechanisms for inhibition of the cdc2-related kinases are likely to exist in NGF treated PC12 cells. The activities of the principal cyclin D1-associated kinases in PCl2 cells, cdk2 and cdk4, are reduced by NGF treatment (see Fig. 5). This reduction in activity may not have resulted from a decrease of the proper cyclin regulatory partner since cyclin D1/cdk2 complexes and cyclin D1/ cdk4 complexes as well as cyclin D1 itself actually accumulate to higher levels in the presence of NGF (see Fig. 4) while the kinase activities decrease. The cdk kinases can be positively regulated by the cdk-activating kinase (CAK) (Desai et al., 1992; Solomon et al., 1992; Kato et al., 1994) and negatively regulated by the binding of cdk inhibitory proteins (reviewed by Peter and Herskowitz, 1994). Cyclin D1 forms complexes only with dephosphorylated inactive cdk2 in both replicating and senescent fibroblasts. Despite the presence of D1, these complexes fail to phosphorylate histone H1 (Dulic et al., 1993; Kato et al., 1993; Bates et al., 1994). Similar mechanisms may contribute to a reduction in kinase activities in $\mathrm{PC} 12$ cells.

Inhibition of cdk 2 kinase activity by a cdk inhibitor has been implicated in cell cycle arrest in G1 by cell-cell contact, TGF$\beta 1$ or $\gamma$-irradiation (Polyak et al., 1994 and Dulic et al., 1994). Polyak et al. (1994) found that inhibition of cdk2 kinase activity by either cell-cell contact or TGF- $\beta 1$ in mink lung epithelial cells was due to binding of a $27 \mathrm{kDa}$ protein to cyclin $\mathrm{F} / \mathrm{cdk} 2$, inactivating the cyclin E/cdk2 complexes. Inhibition of $\mathrm{cdk} 2 \mathrm{ki}$ nase activities by $\gamma$-irradiation in human fibroblasts resulted from the binding of a $21 \mathrm{kDa}$ cdk inhibitor to cyclin E/cdk2 and cyclin A/cdk2 complexes (Dulic et al., 1994). Theses findings imply that downregulation of cdk kinase activities by a cdk inhibitor contributes to cell-cell contact, TGF- $\beta 1$, or $\gamma$-irradiationmediated Gl arrest. Similarly, regulation of cdc2-related kinase activities may contribute to a NGF mechanism for growth arrest. The induction of $\mathrm{p} 21$ in response to NGF may downregulate cdc2-related kinase activities through binding of $\mathrm{p} 21$ to cyclin D1/cdk2 and cyclin D1/cdk4. Thus, NGF may cause a p21-mediated inhibition of cyclin/cdk activity despite the increase in cyclin/cdk complexes that would arrest of cell progression.

One consequence of the downregulation of cdc2-related kinases follows from the fact that the retinoblastoma protein, $\mathrm{Rb}$, appears to be a specific target for the cdk kinases during the $\mathrm{Gl}$ to $\mathrm{S}$ phase transition. The $\mathrm{Rb}$ protein is a negative-growth regulator that prevents $S$ phase entry, and inactivation of this growth-suppressive function is presumed to result from $\mathrm{Rb}$ hyperphosphorylation during the late $\mathrm{Gl}$ phase (Buchkovich et al., 1989: Chen et al., 1989; DeCaprio et al., 1989; Mihara et al., 1989). NGF treatment could lead to dephosphorylation of the $\mathrm{Rb}$ protein by NGF inhibition of the activity of a kinase, such as cdk2, cdk4, and cde2. In agreement we and others (Kalman et al., 1993) observed that $\mathrm{Rb}$ protein accumulates in a hypophosphorylated form in NGF treated PC12 cells as cell division stops and neurites extend.

It is noteworthy that G1 cyclins can physically interact with Rb (Dowdy et al., 1993; Ewen et al., 1993a; Kato et al., 1993). 
Cyclin D2, D3, and E, but not D1, can induce Rb hyperphosphorylation, which has been linked to the loss of the $\mathrm{Rb}$ G1 arrest function (Hinds et al., 1992; Ewen et al., 1993a). Cyclin D1 binds preferentially to the hypophosphorylated form of $\mathrm{Rb}$ in vivo (Dowdy et al., 1993). Results of this report show that induction of cyclin DI and accumulation of unphosphorylated $\mathrm{Rb}$ were correlated with an increase of $\mathrm{D} 1 / \mathrm{Rb}$ complexes during $\mathrm{NGF}$-induced $\mathrm{PCl}^{-} 2$ cell differentiation. The interaction of D-type cyclins with $\mathrm{Rb}$ resembles that of the adenovirus $\mathrm{E} 1 \mathrm{~A}$ protein with $\mathrm{Rb}$ in that it can disrupt $\mathrm{Rb}$ inhibition of $\mathrm{E} 2 \mathrm{~F} / \mathrm{Rb}$ complexes (Dowdy et al., 1993). However, NGF does not affect the level of $\mathrm{Rb} / \mathrm{E} 2 \mathrm{~F}$ complexes as measured by assay of E2F binding activity (Buchkovich and Ziff, 1994). Therefore, interaction of cyclin D1 with unphosphorylated Rb may constitute another basis for regulating the activities of cyclin $\mathrm{Dl}$ or $\mathrm{Rb}$ during cell cycle arrest in the Gl phase.

We have shown that PC12 cells express cyclin D1 as the major D-type cyclin with very low levels of D2 also expressed, and that a large increase of cyclin D1 protein takes place in the NGF treated cell population. An increase of cyclin D1 in NGFinduced differentiated PCl 2 cells is consistent with a recent report (Tamaru et al., 1994). Induction of cyclin D1 is specifically associated with cell differentiation because the agents which are inducers of $\mathrm{DI}, \mathrm{NGF}$ and $\mathrm{FGF}$, can induce $\mathrm{PCl} 2$ cell differentiation, but EGF and insulin, which induce proliferation rather than differentiation, fail to induce D1. A sccond protein, known as SNT, is rapidly phosphorylated on tyrosine in response to differentiation factors, such as NGF and FGF, but not EGF or insulin (Rabin et al., 1993). However, in contrast to the rapid phosphorylation of SNT, the induction of cyclin D1 by NGF is slow, requiring several days for maximum effect, and mostly takes place after PC12 morphological changes have occurred. A particularly intriguing observation is that cyclin D1 induced by NGF in PC12 cells is nuclear (see Fig. 3) even after $13 \mathrm{~d}$ of NGF treatment, a time when the cells have fully differentiated morphologically. Accumulation of cyclin DI in the nucleus of NGF treated cells is consistent with a role for D1 as a cell cycle regulator with nuclear targets. However, this role in NGF arrest of cell cycling appears to conflict with cyclin D1 action in other instances in which DI promotes the opposite processes, Gl progression and cell entry into S phase (Matsushme et al., 1992; Baldin et al., 1993). It has previously been shown that cyclin D1 protein accumulates in human diploid fibroblasts and reaches a maximum level just prior to $S$ phase and that D1 disappears from the nucleus when cells proceed into $S$ phase (Baldin et al., 1993). The turnover of cyclin D1 in the late $G 1$ phase is very rapid, with the protein exhibiting a half-life of less than $20 \mathrm{~min}$ (Matsushme et al., 1992). These findings suggest that degradation of D1 or its exclusion from the nucleus is coupled to, and perhaps required for cell progression into $S$ phase.

The striking results of overexpression of cyclin D1 in 6-24 cells presented here, demonstrate that cyclin D1 can cause an accumulation of cells in $\mathrm{G} 1$ phase and a decrease of cells in $S$ and $\mathrm{G} 2$ phase. In this event, persistent induction of cyclin D1 by NGF could also contribute to the arrest of cells, especially in the Gl phase. Increased levels of cyclin $\mathrm{Dl}$ in the nucleus following NGF treatment could result from insufficient capacity of the cell to degrade this protein. Alternatively, NGF may specifically block cyclin D1 degradation or prevent exclusion from the nucleus, leading to high levels of nuclear cyclin D1. Cyclin DI in this capacity, instead of driving cells into $S$ phase, may cause the cell cycle to arrest. In agreement, Baldin et al. (1993) found that quiescent human fibroblasts which express high levels of cyclin Dl were unable to reenter the cell cycle upon the addition of serum. Difficulties encountered in generating cells that express high levels of cyclin D1 (Quelle et al., 1993) may also reflect cell cycle arrest by cyclin D1. Moreover, overexpression of cyclin D1 in G1 phase by using microinjection causes a cell cycle arrest in late G1 phase (Pagano et al., 1994). These findings support the model that cyclin DI is a critical target of growth arrest signals in G1.

While we have observed the induction of cyclin D1 in NGFinduced differentiated PC12 cells, the withdrawal of NGF also greatly induces cyclin D1 mRNA during programmed cell death of sympathetic neurons from rat superior cervical ganglia (SCG) (Freeman et al., 1994). Freeman et al. (1994) found that sympathetic neurons predominantly express cyclin D2 and D3 prior to NGF withdrawal, while we find that PC12 cells predominantly expressed cyclin D1, rather than D2 and D3. Hence, cyclin D1 may play multiple functions in controlling cell proliferation and differentiation in PC12 cells, while multiple D-type cyclins may act in in sympathetic neurons from the SCG. This is consistent with differences in D-type cyclin expression and activities observed in other systems (Ewen et al., 1993). Further studies will be required to understand the induction of D1 upon withdrawal of NGF.

Based on (1) the biochemical data which demonstrated that NGF causes a decrease in expression and enzymatic activities of the cdc2-related kinases and an accumulation of dephosphorylated Rb, and (2) analysis of DNA content in cells which overexpress cyclin D1 which causes cells to arrest in G1 phase, we would predict that NGF also leads cells to arrest in G1. However, recent studies have shown that NGF leads to an accumulation of $\mathrm{G} 2$ cells, but only a small change of G1 cells during an $8 \mathrm{~d}$ NGF treatment (Buchkovich and Ziff, 1994). Our results with NGF treatment of 6-24 cells, a trkA overexpressing derivative of PC12 cells, shown in Figure 8 are similar. The fact the cyclin D1 decreases the $S$ phase population supports the hypothesis that the increase in cyclin D1 induced by NGF also has a role in PC1 2 cell cycle arrest. However, NGF also induces a number of other changes including the decrease in cdk kinases and $\mathrm{Rb}$ phosphorylation, and elevation of $\mathrm{p} 21$ protein, which could all exert regulatory effects that inhibit cell transit from G1 to $S$. Thus, the mechanism of cell cycle arrest caused by NGF is likely to be more complex than that of cyclin D1 alone, perhaps proceeding in several stages. Further experiments will be necessary to determine which factors are the primary effectors of NGF and the specific role of the induction of cyclin DI in cell cycle arrest.

It is noteworthy that PCNA is a subunit of DNA polymerase $\delta$ (Wang, 1991), and one of the factors required for the initiation of DNA replication and DNA repair (Prelich el al., 1987a,b, 1988; Tsurimoto et al., 1990). The synthesis of PCNA increases during late $\mathrm{Gl}$ and $\mathrm{S}$ phase (Bravo and Macdonald-Bravo, 1987). More recent reports show that the cell cycle arrest by overexpression of cyclin D1 in G1 phase could be overcome by coexpression of PCNA (Pagano et al., 1994). p21 may directly block DNA replication by inhibiting PCNA (Flores-Rozas et al., 1994; Waga et al., 1994). We find that the level of PCNA protein is strongly decreased in NGF treated cells and in 6-24 cells which overexpress cyclin D1. It is also possible that p21 mediates inhibition of expression of PCNA since p21 is upregulated by NGF. An interaction with cyclin D1 could further prevent PCNA from binding to the DNA replication initiation complex, thus suppressing DNA synthesis and blocking reentry into $S$ 
phase. Taken together, elevation of cyclin D1, and blockage of cdk kinase activity caused by increased p21 levels and decreased cdk kinase protein levels, all dependent on NGF, may lead to dephosphorylation of $\mathrm{Rb}$ and repression of $\mathrm{S}$ phase functions such as PCNA. This in turn may cause cell cycle arrest allowing differentiation into neuron like cells.

We note that in budding yeast, mating type pheromone induces growth arrest by inducing the expression of Farl, a factor functionally and structurally related to p21 (reviewed by Peter and Herskowitz, 1994). Farl inhibits yeast CLN/cdc28 complex function in a manner similar to p21 inhibition of cyclin D1/cde4 and cyclin D1/cdk6 function reported here. It will be interesting to determine the extent of mechanistic similarity between yeast and PC12 during growth arrest and differentiation induced respectively by mating type pheromone and NGF.

\section{References}

Akiyama T, Ohuchi T, Sumida S, Matsumoto K, Toyoshima K (1992) Phosphorylation of the retinoblastoma protein by cdk2. Proc Natl Acad Sci USA 89:7900-7904.

Akiyama N, Sasaki H, Katoh O, Sato T, Hirai H, Yazaki Y, Sugimura T, Terada M (1993) Increment of the cyclin D1 mRNA level in TPAtreated three human myeloid leukemia cell lines: HEL, CMK and HL-60 cells. Biochem Biophys Res Commun 195:1041-1049.

Aletta JM, Angeletti R, Liem RK, Purcell C, Shelanski ML, Greene LA (1988) Relationship between the nerve growth factor regulated clone 73 gene product and the 58-kilodaton neuronal intermediate filament protein (peripherin). J Neurochem 51:1317-1320.

Baldin V, Lukas J, Marcote MJ, Pagano M, Draetta G (1993) Cyclin $D 1$ is a nuclear protein required for cell cycle progression in G1. Genes Dev 7:812-821

Bates S, Bonetta L, MacAllan D, Parry D, Holder A, Dickson C, Peters G (1994) CDK6 (PLSTIRE) and CDK4 (PSK-J3) are a distinct subset of the cyclin-dependent kinases that associate with cyclin D1. Oncogene 9:71-79.

Boonstra J, Moolenaar WH, Harrison PH, Moed P, van der Saag PT, de Laat SW (1983) Ionic responses in growth stimulation induced by nerve growth factor and epidermal growth factor in rat pheochromacytoma (PC12) cells. J Cell Biol 97:92-98.

Boulukos KE, Ziff EB (1993) Adenovirus 5 E1A proteins disrupt the neuronal phenotype and growth factor responsiveness of PC1 2 cells by a conser ved region 1-dependent mechanism. Oncogene 8:237-248.

Bravo R, Macdonald-Bravo H (1987) Existence of two populations of cyclin/proliferating cell nuclear antigen during the cell cycle: association with DNA replication sites. J Cell Biol 105:1549-1554.

Buchkovich K, Ziff EB (1994) Nerve growth factor regulates the expression and activity of $\mathrm{p} 33^{\text {cak } 2}$ and $\mathrm{p} 34^{\mathrm{cdc} 2}$ kinases in $\mathrm{PC} 12$ pheochromocytoma cells. Mol Biol Cell 5:1226-1241

Buchkovich K, Duffy LA, Harlow E (1989) The retinoblastoma protein is phosphorylated during specific phases of the cell cycle. Cell 58: 1097-1105.

Burstein DE, Greene LA (1982) Nerve growth factor has both mitogenic and antimitogenic activity. Dev Biol 94:477 482.

Chao MV (1992) Growth factor signaling: where is the specificity? Cell 68:995-997.

Chen P-L, Scully P, Shew J-L, Wang JYJ, Lee W-H (1989) Phosphorylation of the retinoblastoma gene product is modulated during the cell cycle and cellular differentiation. Cell 58:1193-1198.

DeCaprio JA, Ludlow JW, Figge J, Shew J-Y, Huang C-M, Livingston DM (1989) The product of the retinoblastoma susceptibility gene has properties of a cell cycle regulatory element. Cell 58:1085-1095.

Desai D, Gu Y, Morgan DO (1992) Activation of human cyclin-dependent kinase in vitro. Mol Biol Cell 3:571-582.

Dowdy SF, Hinds PW, Louie K, Reed SI, Arnold A, Weinberg RA (1993) Physical interaction of retinoblastoma protein with human D cyclin. Cell 73:499-511.

Draetta G, Beach D (1988) Activation of cdlc2 protein kinase during mitosis in human cells: cell cycle-dependent phosphorylation and subunit rearrangement. Cell 54:17-26.

Dulic V, Kautmann WK, Wilson SJ, Tlsty TD, Lees E, Harper JW, Elledge SJ, Reed SI (1994) p53-dependent inhibition of cyclin-de- pendent kinase activities in human fibroblasts during radiation-induced G1 arrest. Cell 76:1013-1023.

El-Deiry WS, Tokino T, Velculescu VE, Levy DB, Parsons R, Trent JM, Lin D, Mercer EE, Kinzier KW, Vogelstein B (1993) WAF1, a potential mediator of p53 tumors suppression. Cell 75:817-825.

El-Deiry WS, Harper JW, O'Connor PM, Velculescu VE, Canman CE, Iackman I, Pietenpol JA, Burrell M, Hill DE, Wang Y, Wiman KG, Mercer WE, Kastan MB, Kohn KW, Elledge SJ, Kinzier KW, Vogelstein B (1994) WAF1/CIP1 is induced in p53-mediated G1 arrest and apoptosis. Cancer Res 54:1169-1174.

Elledge SJ, Richman R, Hall FL, Williams RT, Lodgson N, Harper JW (1992) CDK2 encodes a 33-kDa cyclin A-associated protein kinase and is expressed before $\mathrm{CDC}^{2}$ in the cell cycle. Proc Natl Acad Sci USA 89:2907-2911

Ewen M, Sluss HK, Sherr CJ, Matsushime H, Kato J-Y, Livingston DM (1993a) Functional interactions of the retinoblastoma protein with mammalian D-type cyclins. Cell 73:487-497.

Ewen M, Sluss HK, Whitehouse LL, Livingston DM (1993b) TGF $\beta$ inhibition of cdk4 synthesis is linked to cell cycle arrest. Cell 74: $1009-1020$.

Flores-Rozas H, Kelnan Z, Dean FB, Pan Z-Q, Harper JW, Elledge SJ, O'Donnell M, Hurwitz J (1994) Cdk-interacting protein 1 directly binds with proliferating cell nuclear antigen and inhibits DNA replication catalyzed by the DNA polymerase $d$ holoenzyme. Proc Nat Acad Sci USA 9:8655-8659.

Freeman RS. Estus S. Johnson EM Jr (1994) Analysis of cell cyclerelated gene expression in postmitotic neurons: selective induction of cyclin D1 during programmed cell death. Neuron 12:343-355.

Gizang-Ginsberg E, Ziff EB (1990) Nerve growth factor induce regulates tyrosine hydroxylase gene transcription through a nucleoprotein complex that contains c-fos. Genes Dev 4:477-491.

Greenberg ME, Greene LA, Ziff EB (1985) Nerve growth factor and epidermal growth factor induce transient changes in proto-oncogene transcription in PC12 cells. J Biol Chem 260:14101-14110.

Greene LA, Tischler AS (1976) Establishment of a noradrenergic clonal line of rat adrennal pheochromocytoma cells which respond to nerve growth factor. Proc Natl Acad Sci USA 73:2424-2428.

Gorham JD, Ziff EB, Baker H (1990) The expression of the neuronal intermediate filament proteins in the rat embryo. Dev Brain Res 57: $235-248$

Gu Y, Turck CW, Morgan DO (1993) Inhibition of CDK2 activity in vivo by an associated $20 \mathrm{~K}$ regulatory subunit. Nature 366:707-710.

Gunning PW, Landreth GE, Layer P, Ignatius M, Shooter EM (1981) Nerve growth factor-induced differentiation of PC12 cells: evaluation of changes in RNA and DNA metabolism. J Neurosci 1:368-379.

Harper JW, Adami GR, Wei N, Keyomarsi K, Elledge SJ (1993) The p21 cdk-interacting protein Cipl is a potent inhibitor of G1 cyclindependent kinases. Cell 75:805-816.

Hawley-Nelson P, Ciccarone V, Gebeyehu G, Jessee J, Felgner PL (1993) LipofectAMINETM reagent: a new, higher efficiency polycationic liposome transfection reagent. Fucus 15:73-83.

Hayes TE, Valtz NL, McKay RDG (1991) Down-regulation of CDC2 upon terminal differentiation of neurons. New Biol 3:259-269.

Hempstead BL, Rabin SJ, Kaplan L, Reid S, Parada LF, Kaplan DR (1992) Overexpression of the trk tyrosine kinase rapidly accelerates nerve growth factor-induced differentiation. Neuron 9:883-896.

Hinds PW, Mittnacht S, Dulic V, Arnold A, Reed SI, Weinberg RA (1992) Regulation of retinoblastoma protein functions by ectopic expression of human cyclins. Cell 70:993-1006.

Hu Q, Bautista C, Edwards EM, Defeo-Jones D, Jones RE, Harlow E (1991) Antibodies specific for the human retinoblastoma protein identify a fanily of related of related polypeptides. Mol Cell Biol 11: 5792-5799.

Huff KR, Guroff G (1979) Nerve growth factor induced reduction in epidermal growth factor responsiveness and epidermal growth factor receptor in PC12 cells: an aspect of cell differentiation. Biochem Biophys Res Commun 89:175-180.

Huff KR, Guroff G (1981) Nerve growth factor-induced alteration in the response of $\mathrm{PC} 12$ pheochromocytoma cells to epidermal growth factor. J Cell Biol 88:189-198.

Ignatius MJ, Chandler CR, Shooter EM (1985) Nerve growth factortreated, neurite-bearing PC12 cells continue to synthesize DNA. J Neurosci 5:343-351.

Johnson EM, Gorin PM JR, Brandeis LD, Pearson J (1980) Dorsal root 
ganglion neurons are destroyed by exposure in utero to maternal antibody to nerve growth factor. Science 210:916-918.

Kalman D, Whittaker K, Bishop JM, O'Lague PH (1993) Domains of $\mathrm{E} 1 \mathrm{~A}$ that bind $\mathrm{p} 105 \mathrm{Rb}, \mathrm{p} 130$, and $\mathrm{p} 300$ are required to block nerve growth factor-induced neurite growth in PC12 cells. Mol Cell Biol $4: 353-361$.

Kato J-Y, Sherr CJ (1993) Inhibition of granulocyte differentiation by G1 cyclins, D2 and D3, but not D1. Proc Natl Acad Sci USA 90: $11513-11517$.

Kato J-Y, Matsushime H, Hiebert SW, Ewen ME, Sherr C J (1993) Direct binding of cyclin $\mathrm{D}$ to the retinoblastoma gene product $(\mathrm{pRb})$ and $\mathrm{pRb}$ phosphorylation by the cyclin D-dependent kinase CDK4. Genes Dev 7:331-342.

Kato J-Y, Matsuoka M, Strom D K, Sherr CJ (1994) Regulation of cyclin D-dependent kinase 4 (cdk4) by cdk4-activating kinase. Mol Cell Biol 14:2713-2721.

Leonard DGB, Gorham JD, Cole P, Greene LA, Ziff EB (1988) A nerve growth factor-regulated messenger RNA cncodes a new intermediate filament protein. J Cell Biol 106:181-193.

Levi-Montalcini R (1976) The nerve growth factor: its role in growth, differentiation and function of the sympathetic adrenergic neuron. Prog Brain Res 45:235-258.

Levi-Montalcini R, Angeletti RV (1968) Nerve growth factor. Physiol Rev 49:534-569.

Lew J, Beaudette K, Litwin CME, Wang JH (1992a) Purification and characterization of a novel proline-directed protein kinase from bovine brain. J Biol Chem 267:13383-13390.

Lew J, Winkfein RJ, Paudel HK, Wang JH (1992b) Brain prolinedirected protein kinase is a neurofilament kinase which displays high sequence homology to p34 cdc2. J Biol Chem 267:25922-25926.

Lin BTY, Gruenwald S, Morla AO, Lee W-H, Wang JYJ (1991) Retinoblastoma cancer suppressor gene product is a substrate of the cell cycle regulator cdc2 kinase. EMBO J 10:857-864.

Maher (1988) Nerve growth factor induces protein-tyrosine phosphorylation. Proc Natl Acad Sci USA 85:6788-6791.

Marraccino RL, Firpo EJ, Roberts JM (1992) Activation of the p34 CDC2 protein kinase at the start of $S$ phase in the human cell cycle. Mol Biol Cell 3:389-401.

Matsushime H, Roussel MF, Ashmun RA, Sherr CJ (1991) Clonnystimulating factors 1 regulates novel cyclins during the G1 phase of the cell cycle. Cell 65:701-713.

Matsushime H, Ewen ME, Strom DK, Kato J-Y, Hanks SK, Roussel MF, Sherr CJ (1992) Identification and properties of an alypical calalytic subunit (p34 ${ }^{\mathrm{PS} K J} / \mathrm{CDK} 4$ ) for mammalian D-type G1 cyclins. Cell 71:323-334.

Matsushime H, Quelle DE, Shurtleff SA, Shibuya M, Sherr CJ, Kato J-Y (1994) D-type cyclin-dependent kinase activity in mammalian cells. Mol Cell Biol 14:2066-2076.

Meyerson M, Harlow E (1994) Identification of G1 kinase activity for cdk6, a novel cyclin D partner. Mol Cell Biol 14:2077-2086.

Mihara K, Cao XR, Yen A, Chandler S, Driscoll B, Murphree AL, Tang A, Fung YK (1989) Cell cycle-dependent regulation of phosphorylation of the human retinoblastoma gene product. Science 246:13001303.

Murray A, Hunt T (1993) Cell cycle: an introduction. New York: W. H. Freeman.

Noda A, Ning Y, Venable SF, Pereira-Smith OM, Smith JR (1994) Cloning of senescent cell-derived inhibitors of DNA synthesis using an expression screen. Exp Cell Res 211:90-98.

Okano HJ, Pfaff DW, Gibbis RB (1993) RB and cdc2 expression in brain: correlations with ${ }^{3} \mathrm{H}$-thymidine incorporation and neurogenesis. J Neurosci 13:2930-2938.

Pagano M, Pepperkok R, Verde F, Ansorge W, Draetta G (1992) Cyclin $\mathrm{A}$ is required at two points in the human cell cycle. EMBO $\mathrm{J} 11$ : 961-971.

Pagano M, Theodoras AM, Tam SW, Draetta GF (1994) Cyclin D1mediated inhibition of repair and replicative DNA synthesis in human fibroblasts. Genes Dev 8:1627-1639.

Parysek LM, Goldman RD (1987) Characterization of intermediate filaments in PC12 cells. J Neurosci 7:781-791.

Peter M, Herskowitz I (1994) Joining the complex: cyclin-dependent kinase inhibitory proteins and the cell cycle. Cell 79:181-184.

Pines J (1993) Cyclins and cyclin-dependent kinases: take your partners. Trends Biochem Sci 18:195-197.

Pines J, Hunter T (1989) Isolation of human cyclin cDNA: evidence for cyclin mRNA and protein regulation in the cell cycle and for interaction with $\mathrm{p} 34^{\mathrm{dd} c}$. Cell 58:833-846.

Pines J, Hunter T (1991) Human cyclins A and B1 are differentially located in the cell and undergn cell cycle-dependent nuclear transport. J Cell Biol 115:1-17.

Polyak K, Kato J-Y, Solomon MJ, Sherr CJ, Massague J, Roberts JM, Koff $\Lambda$ (1994) $\mathrm{p} 27^{\mathrm{kip} 1}$, a cyclin-cdk inhibitor, links transforming growth factor- $\beta$ and contact inhibition to cell cycle arrest. Genes Dev 8:9-22.

Prelich G, Stillman B (1988) Coordinated leading and lagging strand synthesis during SV40 DNA replication in vitro required PCNA. Cell 53:117-126.

Prelich G, Kostura M, Marshak DR, Mathews MB, Stillman B (1987a) The cell-cycle regulated proliferating cell nuclear antigen is required for SV40 DNA replication in vitro. Nature 326:471-475.

Prelich G, Tan C-K, Kostura M, Mathews MB, So AG, Downey KM, Stillman B (1987b) Functional identify of proliferating cell nuclear antigen and a DNA polymerase-d auxiliary protein. Nature 326:517520 .

Quelle DE, Ashmun RA, Shurtleff SA, Kato J-Y, Bar-Sagi D, Roussel MF, Sherr CJ (1993) Overexpression of mouse D-type cyclins accelerates Gl phase in roder fibroblasts. Genes Dev 7:1559-1571.

Rabin SJ, Cleghon V, Kaplan DR (1993) SNT, a differentiation-specific target of ncurotrophic factor-induced tyrosine kinase activity in neurons and PC12 cells. Mol Cell Biol 13:2203-2213.

Riabowol K, Draetta G, Brizuela L, Vandre D, Beach D (1989) The cdc2 kinase is a nuclear protein that is essential for mitusis in mammalian cells. Cell 57:393-401.

Rosenblatt J, Gu Y, Morgan DO (1992) Human cyclin-dependent kinase $2(\mathrm{CDK} 2)$ is activated during the $\mathrm{S}$ and $\mathrm{G} 2$ phases of the cell cycle and associates with cyclin A. Proc Natl Acad Sci USA 89: 2824-2828

Ross ME, Risken M (1194) MN20, a D2 cyclin found in brain, is implicated in neural differentiation. $J$ Neurosci 11:6384-6391.

Rudkin BB, Lazarovici P, Levi B-Z, Abe Y, Fujita K, Guroff G (1989) Cell cycle-specific action of nerve growth factor in PC12 cells: differentiation without proliferation. EMBO J 8:3319-3325.

Schubert D, LaCorbiere M, Whitlock C, Stallcup W. (1978) Alterations in the surface properties of cells responsive to nerve growth factor. Nature 273:718-723.

Sewing A, Burger C, Brusselbach S, Schalk C, Lucibcllo FC, Muller R (1993) Human cyclin D1 encodes a labile nuclear protein whose synthesis is directly induced by growth factors and suppressed by cyclic AMP. J Cell Sci 104:545-555.

Sherr C (1993) Mammlian G1 cyclins. Cell 73:1059-1065.

Solomon MJ, Glotzer M, Lee TH, Phillipe M, Kirschner MW (1990) Cyclin activation of $\mathrm{p} 34^{\text {cdc2 }}$. Cell 63:1013-1024.

Solomon MJ, Lee TH, Kirschner MW (1992) Role of phosphorylation in $\mathrm{p} 34^{\mathrm{cdc} 2}$ activation: identification of an activating kinase. Mol Biol Cell 3:13-27.

Tamaru T, Okada M, Nakagawa $H$ (1994) Differential expression of D type cyclins during neuronal maturation. Neurosci Lett 168:229-232.

Tsai L-H, Harlow E, Meyerson M (1991) Isolation of the human cdk2 gene that encodes the cyclin $\mathrm{A}$ - and adenovirus E1A-associated p33 kinase. Nature 353:174-177.

Tsai L-H, Lees E, Faha B, Harlow E, Riabowol K (1993a) The cdk2 kinase is required for the G1-to-S phase transition in mammalian cells. Oncogene 8:1593-1602.

Tsai L-H, Takahashi T, Caviness VS Jr, Harlow E (1993b) Activity and expression pattern of cyclin-dependent kinase 5 in the embryonic mouse nervous system. Development 119:1029-1040.

Tsurimoto T, Melendy T, Stillman B (1990) Sequential initiation of lagging and leading strand synthesis by two different polymerase complexes at SV40 DNA replication origin. Nature 346:534-539.

van den Heuvel S, Harlow E (1993) Distinct roles for cyclin-dependent kinases in cell cycle control. Science 262:2050-2054.

Waga S, Hannon GJ, Beach D, Stillman B (1994) The p21 inhibitor of cyclin-dependent kinase controls DNA replication by interaction with PCNA. Nature 369:574-578.

Wang TSF (1991) Eukaryotic DNA polymerases. Annu Rev Biochem $60: 513-552$

Won K-A, Xiong Y, Beach D, Gilman M (1992) Growth-regulated expression of D-type cyclin genes in human diploid fibroblasts. Proc Natl Acad Sci USA 89:9910-9914.

Xiong Y, Zhang H, Beach D (1992) D-type cyclins associate with multiple protein kinases and the DNA replication and repair factor PCNA. Cell 71:505-514. 